\title{
Direitos à Vida, ao Próprio Corpo e às Partes do Mesmo (Transplantes). Esterilização e Operações Cirủrgicas para "Mudança de Sexo" ${ }^{\dagger t}$. Direito ao Cadáver e às Partes do Mesmo.
}

\author{
Antônio Chaves \\ Professor Titular de Direito Civil da Faculdade de \\ Direito da Universilade de São Paulo
}

\begin{abstract}
Sumário: 1. A Declaracão Universal dos Direitos Humanos. 2. A preservação do homem quanto ao seu físico. $O$ direito à vida. 3. O aborto. 4. Contenção da natalidade e planejamento familiar. 5. Direito à integridade física. 6. Direito ao próprio corpo. 7. Direito às partes separadas do corpo: o sangue. $O$ sêmen masculino. 8. A cirurgia e a lei penal. $O$ consentimento do paciente. A cirurgia estética. 9. Correção de malformações sexuais. 10. Castraçāo. Esterilização. 11. Transexualismo e operações objetivando "mudança de sexo". 12. Retirada de partes do corpo humano vivo para transplantes. 13. Direito ao cadáver. 14. Retirada de órgãos ou de partes de cadáver. 15. A antropofagia necessária.
\end{abstract}

\section{A Declaração Universal dos Direitos Humanos.}

Nunca, como hoje, o homem sentiu-se tão senhor do universo. Nunca, como agora, acumulou tantos conhecimentos sobre tudo o que o cerca, desde o microcosmo, até o espaço interestelar e os corpos que nele gravitam.

O microscópico eletrônico amplia 650.000 vezes as imagens, penetrando quase que na intimidade das células e dos átomos, numa proporção que alargaria para um quilômetro o diâmetro do anel que temos no dedo.

Os satélites artificiais devassam os espaços sem fim: viagens à Lua deixaram há muito de ser novidade, e nossa atenção, passando por Vênus, Marte e outros corpos celestes dirigir-se-á fatalmente para novos alvos. 
Diligentemente os juristas procuram acompanhar as possíveis consequiências dessas conquistas e estudam, no silêncio dos seus gabinetes, redigindo artigos, relatórios, ou discutem, no estrépito das reuniões e congressos internacionais, todos os seus desdobramentos públicos e privados, facilitando aos Governos a redação das leis e dos tratados.

Um setor todavia existe em que, surpreendentemente, menos profícua tem sido entre nós essa curiosidade: sobre o que é efetivamente, o fundamento, a razão de ser, a finalidade de todas as coisas: o próprio homem.

Afonso X, o Sábio, já havia consignado na Partida VII, Livro 26 que "la persona del ome es la más nobre cosa del mundo".

Somente agora os juristas pátrios começam a perceber que o maior dos conselhos dado por Sócrates: o nosce te ipsum, a eles também é dirigido.

E certo que a psicologia e a psicoanálise, a partir de SIGISMUND FreUd, continuando com ALFRED AdLER, C. G. JUNG, OtTo RANK, Karen HorNEY, ERICH Fromm, HaRry STACK SULLIVAN e tantos outros, conseguiram penetrar nos mais íntimos refolhos da alma humana.

Mas para a idéia fundamental, lançada há 2.300 anos pela sabedoria grega, contida na sentença do próprio Sócrates, de que entre as muitas coisas maravilhosas do mundo, a maior de todas é o homem, de há poucos decênios a esta parte é que começaram a despertar os jurisconsultos.

$\mathrm{E}$ que imensidão e variedade inesperada de panoramas se nos defronta aos olhos maravilhados a partir do momento em que os jurisperitos, principalmente franceses, italianos e alemães, começaram a desdobrar seus estudos em dois grandes setores, cujos contornos começam a definir-se: os direitos fundamentais da pessoa (" direitos do homem") e os direitos da personalidade.

Na grande e um tanto empírica, mas necessária divisão dos direitos em pecuniários ou materiais e extrapecuniários, impropriamente denominados morais, o espaço até há pouco ocupado quase que exclusivamente p.or aqueles, começa a ceder terreno a estes.

Claro que nunca, na prática, os contornos se apresentam nítidos; todo direito pecuniário tem reflexos de ordem moral; todo direito extrapecuniário tem repercussões no âmbito patrimonial do indivíduo. 
Tinham pois razão HENRI, LÉon e JEAN MAZEAUd ao condenarem a teoria clássica segundo a qual os direitos da personalidade não formam parte do patrimônio:

"Há que afirmar ao contrário, que o patrimônio é o continente de todos os direitos pecuniários ou não pecuniários, que vão fundir-se nele; sua influência recíproca é demasiado grande para que possam dissociar-se alguns dos seus elementos. 0 direito francês repara o dano moral, e essa reparação, em quase todos os casos, calcula-se; como se conceberia que fosse introduzido assim um valor pecuniário, a título de reparação, no patrimônio, se não fosse para substituir outro valor, pecuniário ou moral, que desapareceu?"

Basta acompanhar as declarações fundamentais de direitos da humanidade, para que se verifique como foram se definindo e concretizando, desde a Magna Carta outorgada pelo Rei João Sem Terra, em 1215, passando pela Grande Carta de Henrique III, de 11-02-1225, pelo Bill of Rights de 1689, pela Declaração de Direitos da Virgínia, de 12-06-1776, pela Declaração dos Direitos do Homem e do Cidadão de 02-10-1789, pela Declaração dos Direitos do Homem e do Cidadão, de 1793, até a Declaração Universal dos Direitos do Homem, aprovada em resolução da III Seção Ordinária da Assembléia Geral das Nações Unidas, levada a efeito em Paris, aos 10-12-1948.

É este último um documento fundamental da nossa civilização, objeto de abundante bibliografia referida por EDUARDo MuYlaERT ANTUNES, Natureza Jurídica da Declaração Universal dos Direitos Humanos, in Rev. dos Tribunais, v. 446, 1972, p. 27-36.

Ressalta que, como simples recomendação que é da Assembléia Geral das Nações Unidas, não cria, por si mesma, obrigações jurídicas para os Estados-Membros da Organização.

Sua contribuição ao definir os Direitos do Homem já se reflete, no entanto, em inúmeros textos constitucionais ou legais, registrando-se alguns progressos notáveis no plano das organizações regionais :

"A Convenção Européia dos Direitos Humanos, assinada em Roma em 04-11-1950, entrou em vigor em 03-09-1953. O direito de petição dos indivíduos à Comissão Européia dos Direitos Humanos foi reconhecido por 11 Estados, que aceitaram também a 
competência jurisdicional da Corte Européia de Direitos Humanos."

Doze países latino-americanos subscreveram, em São José da Costa Rica, a Convenção Americana dos Direitos Humanos em data de 21-11-1969, que prevê uma Comissão e uma Corte de Direitos Humanos, a entrar em vigor com a ratificação ou adesão por onze membros da Organização dos Estados Americanos.

Conclui, embora a proteção internacional dos Direitos do Homem não seja ainda uma realidade efetiva, com J. RIVERo, que:

“A Declaração Universal dos Direitos Humanos se impõe com "o valor da afirmação de uma ética universal" e conservará sempre seu lugar de símbolo e de ideal."

Um novo e controvertido impulso recebeu a aplicação desses princípios em virtude da atuação do Presidente norte-americano JAMES CARTER, reafirmada em seu discurso proferido na oNU no dia 17-03-1977, colocando o programa da universalização dos direitos humanos como ponto central da sua política externa.

Tendo as 150 nações-membros que subscreveram a Carta da oNU assumido o compromisso de reafirmar, com o seu comportamento,

"a fé nos direitos fundamentais do homem, na dignidade e no valor do ser humano, na igualdade de direitos de homens e de mulheres",

e como esses valores obtiveram assim consagração no âmbito internacional, não há o que increpar na lógica do seu raciocínio quando lembra que suas cláusulas, da mesma forma que as do acordo de Helsinque, devem ser respeitadas:

"Quando uma violação grosseira ou generalizada acontecer - contrariamente aos compromissos internacionais e à preocupação de todos - os compromissos solenes do Estatuto da ONU, da Declaração Universal dos Direitos Humanos, dos acordos de Helsinque e de muitos outros instrumentos intercionais devem ser levados tão a sério como os acordos comerciais ou de segurança".

Na seqüência de seus artigos, a Declaração consagra os seguintes direitos fundamentais: à liberdade e igualdade, à vida, à segurança pessoal, à isenção de tortura e maus tratos, ao 
reconhecimento como pessoa, à proteção legal, à liberdade, à justiça, à defesa, ao segredo, à honra, à locomoção, ao asilo, à nacionalidade, a contrair casamento, à propriedade, à liberdade de pensamento, consciência e religião, à liberdade de opinião, de reunião, de tomar parte no governo, à previdência social, ao trabalho e à igual remuneração por igual trabalho, ao repouso e ao lazer, à saúde e bem-estar, à instrução, às artes, ao progresso científico, à produção científica, literária ou artística, à ordem social e internacional, ao pleno desenvolvimento de sua personalidade.

Divergem os juristas na classificação dos direitos que são inerentes à pessoa humana. Uns nem sequer se preocupam em enumerá-los, outros, dilatando excessivamente o número, conseguem apenas diluir e complicar as linhas mestras da construção jurídica, terceiros apresentam uma ordenação cuja imperfeição ressalta à primeira vista.

Mas no conglomerado, não apenas desses; como de outros direitos fundamentais do homem moderno, uma distinção é necessário estabelecer para não incidir no erro, apontado pelos MAZEAUD, de confundir os direitos fundamentais do homem com os direitos da personalidade:

"Alguns direitos pecuniários" - acentuam à pág. 268, que portanto não constituem direitos da personalidade, como o direito de propriedade, consideram-se como essenciais para o homem. Ao contrário, se a maioria dos direitos da personalidade, por razão de seu íntimo vínculo com o titular, são direitos do homem, alguns não têm um caráter primordial: o "direito à própria imagem", que nos permite opor-nos à reprodução de nossa fotografia, não é um direito do homem."

Encarecem a necessidade de compreender que o âmbito próprio dos direitos do homem é constituído essencialmente por relações de Direito Público, único que possibilita a proteção dos direitos essenciais do indivíduo contra a arbitrariedade do Estado:

"Quando se examinam os direitos da personalidade, estamos, sem dúvida, em geral, frente aos mesmos direitos mas sob o ângulo do direito privado; isto é, das relações entre os particulares; trata-se de defender esses direitos, já não contra a usurpação pela autoridade, mas contra os ataques dos particulares". 


\section{A Preservação do Homem Quanto ao Seu Físico. 0 Direito à Vida.}

Atendo-nos à nossa matéria, será proveitoso separar, dentre direitos fundamentais da pessoa (direitos do homem), os que se relacionam, ainda que por via reflexa, predominantemente à preservação do seu corpo, dos que de maneira especial, procuram resguardar o integral respeito aos diferentes aspectos do seu psiquismo.

Entre os primeiros ressaltaremos então os direitos à vida, preservação da sua integridade física, ao seu corpo, em vida e após a morte, às partes dele destacadas.

Entre os segundos arrolaremos os que se relacionam antes ao respeito ao resguardo moral da pessoa humana, isto é, os direitos: à preservação da sua integridade psíquica, à honra, ao nome, à própria imagem, ao sigilo; à intimidade; à liberdade intelectual; à liberdade de consciência e de culto; moral de autor, à segurança, à propriedade, à ação.

Nem será prematuro prognosticar que, na busca perene de uma estabilidade que paire acima das paixões e das contingências do momento, os primeiros tenderão a se cristalizar em convenções internacionais, ao passo que estes procurarão se afirmar nas constituições de cada País.

É neste sentido que ADRIANo DE CUPIS alude a uma parcial constitucionalização dos direitos da personalidade, que por essa forma se procura amparar contra o arbítrio do legislador e do próprio Estado:

"Il congegno che garantisce tale stabilità, é rivolto a impedire quella instabilità che si notava proprio sul terreno del Diritto Publico per il prepotere dello Stato nei confronti degli individui. Proprio perchè le manomissioni legislative, come dimonstra la storia, si verificano com frequenza in quella sfera, si é introdotto il detto rimedio".

Tenha-se porém presente ser preferível a expressão Direitos Fundamentais da Pessoa à comumente usada de Direitos do Homem, pois não há direito que não sejä do homem.

CARL SchmitT, Teoria de la Constitución, Madri, tradução, sem data, acentua que o autêntico direito fundamental do indivíduo é sempre absoluto e corresponde ao princípio de distribuição do Estado de direito, segundo o qual a liberdade 
do indivíduo é ilimitada em princípio e a faculdade do Estado, limitada em princípio (p. 203/4).

Não há como não considerar, em primeiro lugar, o direito à vida, direito inato, fundamental, o mais essencial dos direitos, pois dele dependem, é óbvio, não apenas todos os demais, como o seu aproveitamento.

E sem dúvida relevante o interesse público na salvaguarda desse bem supremo, como revela, aliás, o fato da Constituição ressalvá-lo em primeiro lugar, e da Parte Especial do Código Penal ter início exatamente com a especificação dos crimes contra a vida, aos quais, por outro lado, comina as penalidades mais severas.

Desde as épocas mais primitivas - assinala ADRIANO DE CUPIS, - cada grupo social sentiu a exigência de não tolerar dissídios internos capazes de comprometer, com a incolumidade dos seus membros, também a sua consistência e a sua força frente aos demais grupos rivais. Adita ainda o reclamo, por qualquer Estado, de garantir um mínimo de ordem e de segurança interna indispensável a um convívio civilizado.

Consigna, ao mesmo passo, dois caracteres fundamentais do direito à vida: é inato, porquanto cabe ao indivíduo pelo simples fato de ser munido da personalidade adquirida com o nascimento; é um direito privado, pertence a cada um como indivíduo, isto é, considerado no círculo das finalidades que tem como simples ser humano, não perdendo semelhante característica nem mesmo quando se dirija para o Estado.

Devia, por isso mesmo, no âmbito civil, ser correspondentemente a mais ampla possível, e não uma ridicularia como a do art. 1537 do Código Civil (pagamento das despesas com o tratamento da vítima, seu funeral e luto da família, e prestação de alimentos às pessoas a quem o defunto as devia) a sanção civil da indenização no caso de homicídio, que fatalmente terá que ser substituída por outra, mais condizente com a realidade da vida.

Coloca-se, com isso, o delicado problema de saber quanto vale a vida de um homem.

São numerosos e interessantes os problemas relacionados com o assunto em exame.

Em primeiro lugar, o das limitações do direito à vida, consubstanciado, antes de mais nada, na controvertida questão da pena de morte. 
Da mesma forma que a Lei Fundamental de Bonn, § 2., alínea a, da Constituição italiana de 1948, todas as nossas Constituições Federais, a exemplo da atual, art. 153, “caput", sempre asseguraram, aos brasileiros e a.os estrangeiros residentes no País a inviolabilidade dos direitos concernentes à vida, à liberdade, à segurança e à propriedade, nos termos que especifica. Consigna, na $1 .^{\mathrm{a}}$ parte do $\S 11$, que "Não haverá pena de morte, de prisão perpétua, de banimento, ou confisco, salvo nos casos de guerra externa, psicológica adversa, ou revolucionária, ou subversiva, nos termos que a lei determinar.

Temos ainda a legítima defesa, isto é, a faculdade que o Código Penal outorga a quem, "usando moderadamente dos meios necessários, repele injusta agressão, atual ou iminente, a direito seu ou de outrem"

Intimamente relacionados são também os problemas do consentimento da vítima e o da eutanásia. Admitir-se que cada qual se atribua o julgamento da conveniência, mesmo a pedido, de tirar a vida do próximo, seria, sem dúvida, colocar em grave perigo a organização e a boa ordem social. Nem ao próprio interessado reconhece-se a possibilidade de privar-se da vida: menos plausível ainda seria alcançar-se o objetivo por intermédio de terceiro.

Existe, como se percebe, um conjunto de normas, que podem ser rastreadas em todas as legislações, quando não explícitas, nelas contidas implicitamente, e que são tão essenciais que mal se concebem separadas do próprio conceito de civilização e de acatamento à pessoa humana.

O respeito à vida e aos demais direitos correlatos decorre de um dever absoluto por sua própria natureza, ao qual a ninguém é lícito desobedecer:

"O conteúdo de tal dever é vasto, simples e denso, e importa numa atitude geral de preservação do bem tutelado", correspondendo a um "ius unius erga omnes", que, - como não escapou a WALTER Moraes, Adoção e Verdade, S. Paulo, Ed. Rev. dos Tribunais, 1974 , p. 60 - comporta um poder de agir de grande extensão."

$\mathrm{E}$ é justamente por ser tão simples e tão genérica que raramente a "norma agendi" se enuncia nos sistemas legislativos, que mais se detêm no exame de situações particulares, "e acabam por declarar só as exceções e os pormenores da disciplina". 
Do ponto de vista social, é ao Poder Público que cabe combater a degradação humana que leve à morte: a miséria, a fome, as endemias, por todos os meios ao seu alcance.

No âmbito individual, o Código Civil limita-se a reconhecer a legitimidade da exigência dos parentes, uns dos outros, dos "alimentos de que necessitem para subsistir".

Encontramo-nos, diante de toda uma série de prerrogativas que parecem como que levitar sobre os textos legislativos; dir-se-ia que prescindem de qualquer expressão gráfica.

Que espécie de "civilização" é a nossa que sente necessidade de preceitos reconhecendo à pessoa humana o direito à vida, à savalguarda do seu brio, à proteção da sua dignidade?

Igualdade perante a lei, inviolabilidade de consciência, direito de escolher seus governantes, não parecem direitos tão simples, tão fundamentais, que dispensariam qualquer menção expressa?

$\mathrm{E}$ no entanto, quantos vilipêndios nossa geração, tão orgulhosa de seu progresso técnico, continua assistindo entre consternada e perplexa!

$\hat{E}$ claro que repercussões existem sempre, e profundas, no âmbito do Direito Civil, do Direito Penal, e Processual.

Mas no âmbito interno, apenas a Constituição será sede adequada de normas dessa natureza.

Intimamente relacionado é o problema do suicídio.

Depois de interessante digressão histórico-literária, demonstra TEUCRo BRASIELlo que a moral e a religião negam qué o suicídio seja lícito e a ciência médica o considera uma aberração.

O homem não vive para si, exclusivamente; e é de alto interesse para o Estado que o indivíduo seja conservado, porque da soma dos sujeitos decorre a consociação civil, colaborando os homens - cada um no próprio setor - em benefício da coletividade, mesmo que a finalidade imediata seja a satisfação de exigências pessoais. Ora, se um direito sobre a própria pessoa fosse admissível, como um sobre os bens, entraria no conceito de "abuso de direito" a dispersão e lançamento que alguém faça da própria existência...

A lei penal não persegue o suicida por imposição de política jurídica: ou a morte ocorreu, e falta o sujeito passivo da perseguição, ou não ocorreu, e o temor de um castigo poderia levar o agente a reiterar, com mais uma razão, sua tentativa. 
Pretendia ENRICo FERRI tivesse o homem tanto o direito de viver como o de morrer, deixando a sociedade de ter qualquer interesse no próprio momento que ele põe termo à vida.

Poucos argumentos são todavia necessários para demonstrar não ser admitida a faculdade do suicídio, bastando lembrar que o Código Penal comina pena de reclusão ao induzimento, instigação ou auxílio a suicídio.

A ausência de norma incriminadora do próprio agente não pode levar à conclusão de que o suicídio constitua um direito. A finalidade é não agravar a situação daquele que inutilmente o tentou, deixando no entanto bem clara o legislador a intenção de não tolerar qualquer renúncia ao bem da vida.

Não há evidentemente como confundir a hipótese com a recusa ao tratamento médico, prevista no art. 32 do Projeto ORLANDo GOMES: "Ninguém pode ser constrangido a submeter-se a tratamento cirúrgico ou a tratamento médico com risco de vida".

\section{O aborto}

É considerado pelo Código Penal sob duas modalidades: provocado em si mesma pela gestante, ou consentindo em que seja ocasionado por outrem, dando margem à aplicação de pena de detenção de um a três anos (art. 124). Ou provocado por terceiro (art. 125), sem o consentimento da gestante, reclusão de três a dez anos; sem aquele consentimento, reclusão de um a quatro anos (art. 126, caput).

Assume forma qualificada, agravando as penas, se, em conseqüência do aborto ou dos meios empregados para provocá-lo, a gestante sofre lesão corporal de natureza grave; e são duplicadas se por qualquer dessas causas, lhe sobrevém a morte.

Não é punido o aborto necessário, isto é, o praticado por médico (art. 128) :

I. se não há outro meio de salvar a vida da gestante;

II. se a gravidez resulta de estupro e o aborto é precedido de consentimento da gestante ou, quando incapaz, de seu representante legal.

Além de alterar as denominações e as penas, o Código Penal de 1969 ainda desdobra o atual art. 128 em dispositivos 
independentes. Dandó maior compreensão ao item II, separa-o, sob a epígrafe de "aborto por motivo de honra":

"Art. 127 - Provocar aborto em si mesma, para ocultar desonra própria:

Pena - detenção, de seis meses a dois anos.

Parágrafo único - $\mathrm{Na}$ mesma pena incorre quem provoca o aborto, com consentimento da gestante, para ocultar-lhe a desonra.

A segunda figura é objeto do art. 129, aborto terapêutico, que não considera crime o aborto praticado por médico, quando é o único recurso para evitar a morte da gestante, devendo porém (parágrafo único) preceder sempre que possível a confirmação ou concordância de outro médico.

Também catalogado o aborto preterdoloso, que resulta do emprego de violência contra mulher, cuja gravidez não ignora ou é manifesta.

Por outro lado, o art. 20 da Lei das Contravenções Penais pune com multa de 50 centavos a cinco cruzeiros "anunciar processo, substância ou objeto destinado a provocar aborto ou evitar a gravidez", o que é também preceituado no Código de Ética Médica, art. 56.

O Senador VASCONCElos ToRRES apresentou o Projeto de Lei n. 96, de 1971, "incluindo entre os casos de aborto não criminosos ou praticados por médico quando a gravidez resultar de incesto, constituir grave ameaça à saúde da gestante ou envolver risco do filho nascer física e mentalmente, lesado".

O projeto consubstanciava sugestão dos médicos participantes da 19. ${ }^{\text {a }}$ Jornada Brasileira de Ginecologia e Obstetrícia, realizada no Rio de Janeiro, afirmando os especialistas na matéria que tais medidas contribuiriam de forma efetiva e real, para reduzir as tristes estatísticas de mortes provocadas pela ação ineficiente, incapaz e mesmo criminosa, de grande número de parteiras curiosas.

Tanto a Comissão de Constituição de Justiça, como a de Saúde, pelos pareceres $n .^{\circ} \mathrm{s} 641$ e 642 , segundo se verifica no Diário do Congresso Nacional, seção II de 27-11-1971, p. 6710-6711, chegaram à conclusão de que das três alterações propostas, quanto ao mérito: incesto; ameaça à saúde, risco de deformação para o concepto, a primeira era de aferição inviável face o art. 358 do Código Civil, que próibe a investigação de paternidade de filhos incestuosos, a segunda já está 
consagrada no Código Penal, quando se refere à hipótese de "não haver outro meio de salvar a vida da gestante", e a terceira, em sua redação:

"Se a gravidez envolver elevado risco de o concepto nascer, física ou mentalmente, lesado" era aceitável não só do ponto de vista moral e jurídico, como também sob o aspecto médico-científico, face os recentes "efeitos secundários, com reflexos na gestação, de algumas drogas".

Como, porém, o novo Código Penal, que já teve tantas vezes adiada a sua vigência, estava sendo objeto de estudos e revisões por parte do Poder Executivo, sendo provável portanto, a sua apreciação pelo Congresso Nacional, onde o assunto seria amplamente discutido e analisado, seria inconveniente, no momento, a aprovação da proposta, que, embora constitucional, alterava a sistemática do novo direito, todo voltado para proteger a vida.

Fazendo um interessante apanhado histórico que aborda inclusive a influência do Direito Canônico, e passando em revista as mais diversificadas legislações modernas, define Ana Valderez A. N. De Alencar, Aborto in Rev. de Informação Legislativa, n. ${ }^{\circ} 35,1972$, ps. $409-450$ :

"No conceito médico-obstétrico, aborto é a expulsão natural ou provocada, até ao final do sexto mês de gravidez, do produto não viável da concepção; a partir do sexto mês, face à viabilidade do feto, a expulsão passa a denominar-se parto prematuro. A obstetrícia, para efeito de denominação, não faz diferença entre a expulsão espontânea ou provocada".

Aponta a situação legal do aborto nos diferentes países. A prospecção real, acusa a avalancha de abortos clandestinos praticados em todo o mundo, assumindo, no Brasil, proporções alarmantes de verdadeira doença endêmica, como a malária, a esquitossomose e outras; calcula-se serem feitos um milhão e quinhentos mil abortos por ano, correspondendo a $22 \%$ dos partos e $25 \%$ dos leitos existentes em toda a rede hospitalar.

Conclui necessitar o problema de maiores atenções das autoridades:

"Uma campanha intensa, direta e persistente, sobre os males físicos e morais do aborto; um programa, realizado em termos de fatos, de assis- 
tência sanitária às mães pobres; a melhoria do padrão econômico das classes desprotegidas; 0 amparo decisivo de caráter sócio-econômico à mãe solteira, seriam medidas muito mais eficazes de que todo um código, especificamente construído para condenar as práticas abortivas. Dentro desse sistema, os anticoncepcionais contariam, mas em casos particulares, a critério médico; o aborto, em hipóteses excepcionalíssimas reguladas nos termos das leis penais".

\section{Contenção da Natalidade e Planejamento Familiar.}

É outro tema intimamente relacionado com o anterior, a que faremos uma simples referência remetendo a outra publicação da mesma ANA VALDEREZ A. N. DE ALENCAR, Explosão Demográfica: Controle da Natalidade e Planejamento Familiar, n. ${ }^{\circ} 37,1973$, da referida Rev. de Informação Legislativa, p. 175-236, apontando riquíssima bibliografia especializada.

Acompanha a expansão das teorias populacionais, desde os precursores de THOMAs RoBERT MALTUS. A população do globo vem duplicando em espaço de tempo cada vez menor: no início da era cristã, atingiu 300 milhões; em 1650 superava meio bilhão; alcançou um bilhão em 1850; em 1925 chegou a dois bilhões e setecentos e cinqüenta milhões; por volta de 1960 superou a casa dos três bilhões, prevendo-se que, em 1980 , o contingente humano chegue aos quatro bilhões, passando a cinco em 1990 e a dez bilhões no ano de 2025 .

Num relato da campanha voltada para a diminuição dos nascimentos, faz ver, com WALTER RODRIGUES, que:

"Planejar a família não é forçosamente impedir a natalidade, é trazer ao mundo indivíduos aos quais se deverão dar as condições de vida necessárias ao seu desenvolvimento digno. A necessidade de um estudo sobre o planejamento familiar está justificada do ponto de vista sociológico, econômico, sanitário e religioso. Permitir que entidades devidamente registradas possam proceder à educação do público para planejamento de família, sempre assessoradas por médicos e técnicos da matéria. Possibilidade de estudo de uma legislação destinada a instituir o ensino e difusão dos meios anticoncepcionais nos casos com justa 
indicação. É imperioso que medicamentos de efeitos anticoncepcionais sejam incluídos na exigência da receita médica para a sua venda ao público".

$\mathrm{Na}$ ocasião em que essas palavras foram proferidas, dia 26-11-1965, por ocasião da XV Jornada Brasileira de Obstetrícia e Ginecologia, foi fundada a Sociedade Civil "Bem-Estar Familiar no Brasil - BEMFAM", que se propõe alcançar a finalidade indicada em sua denominação, planejando a família. Teve a ressonância indicada pelo surgimento de diversas unidades regionais em diferentes pontos do País: Pará, Ceará, Rio Grande do Norte, Paraíba, Pernambuco, Espírito Santo, Minas Gerais, S. Paulo, Paraná, Rio Grande do Sul, Goiás.

Conclui a pesquisadora seu precioso estudo consignando ser a maioria adepta do planejamento familiar, pela elevação do nível de vida e conseqüente melhoria nas condições de alimentação, saúde, educação, etc.

Admite a necessidade de que o Estado participe dos programas de planejamento, como coadjuvante imprescindível nos setores técnico e financeiro: nunca na qualidade de mandante, pois o brasileiro jamais conceberia ver, na intimidade do lar, a autoridade pública a lhe ditar quando ter filhos e qual o seu número.

"Planejar a família em função da qualidade psicossomática dos seus membros, através de meios que não impliquem em aborto, não sejam lesivos à saúde e sejam praticados por livre e espontânea vontade dos casais.

Nunca o controle em massa, como medida acauteladora contra a fome, a miséria e a morte".

\section{Direito à Integridade Física.}

Embora relevante a posição hierárquica do bem representado pela integridade física, não há dúvida que é inferior ao pressuposto fundamental representado pela própria vida, sendo, por isso mesmo, menos graves as sanções penais correspondentes à sua violação.

A razão é explicada por ADRIANO DE CUPIS: o interesse público relativo à integridade física somente parece digno de proteção quando a mesma integridade constitua condição de 
convivência normal, de segurança da atividade individual. $\mathrm{O}$ mesmo ocorre no setor civil: a ação de ressarcimento diz respeito não à proteção de uma integridade física genérica, mas a determinados aspectos, particularmente importantes deste bem.

Apresenta o exemplo daquele que, sem consentimento da vítima, corta-lhe os cabelos ou a barba: não atinge qualquer direito à integridade física.

Consagra esse autor 57 páginas ao estudo da matéria.

$\mathrm{Na}$ impossibilidade de acompanhá-lo na minuciosa resenha, detenhamo-nos a respeito de três aspectos de particular interesse.

0 primeiro é relativo às operações cirúrgicas, que distingue conforme se destinem, ou não, ao benefício da saúde daquele em cujo corpo são executadas.

A finalidade curativa, ou meramente estética da operação, exclui que se possa invocar contrariedade aos bons costumes, à lei ou à ordem pública. Tratando-se de operação de que não decorra diminuição permanente da integridade física, não há obstáculo à validade do consentimento: pode-se, pois, dispor validamente da própria integridade física, mediante consentimento à operação.

Será nulo, ao contrário, o consentimento a operação cirúrgica capaz de produzir uma diminuição permanente da integridade física, a menos que ocorra estado de necessidade.

Com relação às atividades esportivas, e, de maneira especial, as de caráter violento, como o box, o karatê, a luta livre, lembra que quem participa desses embates consente às lesões que poderá sofrer, aceita o perigo de padecê-las e, por mais que procure evitá-las, não poderá considerá-las alheias à própria vontade.

Com relação aos atos de autolesão, para os quais é estabelecido um regime de rigor que não existe para o suicídio, lembra haver casos em que está em jogo o interesse demográfico do Estado (por exemplo, aborto provocado em si mesma pela mulher) ou é visada finalidade fraudulenta (mutilação para conseguir o pagamento de um seguro, ou para obter a isenção do serviço militar).

A não ser em casos taxativamente previstos, não haverá crime, uma vez que, entre nós, o Código Penal só considera 
lesão corporal a ofensa à integridade corporal ou à saúde de outrem.

Outra artimanha é sem dúvida a "restauração" anatômica da virgindade.

Estudando a Virginoplastia e Direito Penal, in Rev. dos Tribunais, v. 352, p. 23-26, faz ver SERRANo NEvES que se o conceito de virgindade correspondesse, como se pretende, à integridade himenal, burlada, pela natureza desta, a argúcia pericial, muitos conquistadores acabariam respondendo por crime de sedução, passando os códigos penais a ser instrumento de fraude.

Precisam as codificações acertar rapidamente o passo com a realidade, pois do elenco dos crimes definidos na vigente codificação, o que mais se aproxima da hipótese seria o de estelionato, tendo-se em vista a fraude desencadeadora do resultado imoral e antijurídico. E todavia crime contra o patrimônio, e este não seria senão em casos raros o objetivo visado pela trama.

Assim, não caindo, à perfeição, na reprovação de qualquer preceito penal, tanto a pretensa paciente como o cirurgião ficariam à margem de qualquer ação penal, como vem ocorrendo, com grave risco dos salutares propósitos da lei repressiva.

\section{Direito ao Próprio Corpo.}

Sabemos que entre muitas outras divisões, os direitos podem ser pessoais e reais.

Mas em nenhuma destas duas categorias enquadra-se o direito que tem a pessoa sobre o próprio corpo, parecendo, pelo menos à primeira vista, contraditório que um indivíduo possa ser, ao mesmo tempo, sujeito e objeto do direito.

Procura-se solucionar o problema sob alegação de que, como conseqüência da separação, as partes deixam de integrar o corpo, convertendo-se em coisas no sentido jurídico, que podem ser objeto de propriedade e de comércio.

Fadda e Bensa, citados por José Castán Tobenas qualificam, todavia, de excessivamente absolutas semelhantes afirmações. "A propriedade e a comerciabilidade das partes separadas somente têm lugar enquanto que a lei e os bons costumes não se oponham. Não se pode traçar um critério 
geral. Certas partes, por exemplo, cabelos, unhas, dentes, quando sejam separadas, serão objeto de comércio jurídico. Certas outras poderão ser objeto de propriedade somente em determinados casos e para certas finalidades: por exemplo, para experimentos científicos, para preparações de museus, etc.".

O Código Civil italiano prevê a hipótese no artigo:

"5. Atos de Disposiçấo do Próprio Corpo. Os atos de disposição do próprio corpo são proibidos quando ocasionem uma diminuição permanente da integridade física, ou quando sejam de outro modo contrários à lei, à ordem pública ou aos bons costumes".

Seguiu-lhe o exemplo o Projeto Orlando Gomes:

"Art. 29 - Atos de Disposição do Próprio Corpo. Os atos de disposição do corpo são defesos quando importem diminuição permanente da integridade física ou contrariem os bons costumes.

Parágrafo único - $\mathrm{O}$ ato de disposição parcial admite esta por exigência médica."

Deu-lhe melhor redação o Projeto de 1975:

"Art. 13 - Salvo exigência médica, os atos de disposição do próprio corpo são defesos quando importarem diminuição permanente da integridade física, ou contrariarem os bons costumes.

Parágrafo único -- Admitir-se-ão, porém, tais atos para fins de transplante, na forma estabelecida em lei especial."

AdHerbal GonÇALVEs, com muita didática, distinguia três aspectos fundamentais (corpo da pessoa viva, partes destacadas do mesmo, cadáver), mas Pietro Perligieri faz ver que, na verdade, a problemática relativa aos atos de disposição do próprio corpo é dúplice. De um lado, os entre pessoas vivas, isto é, realizados pelo indivíduo frente a outras pessoas vivas; de outro, os assim denominados atos de disposição do próprio corpo feitos em vida, mas desenvolvendo sua eficácia post mortem, relativos à disponibilidade do cadáver.

Quanto ao primeiro aspecto, poder-se-ia, no direito brasileiro reconhecer a disponibilidade sobre o próprio corpo como um todo? 
Com relação à pessoa viva, é claro que não: admiti-lo seria compactuar com a possibilidade do suicídio, tese já repelida, ou da pessoa vender a si própria como escrava, inconcebível perante os postulados de uma nação civilizada.

Mas na legislação, não iremos encontrar qualquer dispositivo explícito a respeito. Seria aliás desnecessário tão implícito está no próprio conceito de pessoa.

Nem deixa de ser matéria relativa à disponibilidade do próprio corpo o resguardo à liberdade sexual, que o Código Penal procura proteger nos artigos 213-216, seguido dos relativos à sedução e corrupção de menores e ao rapto.

Reconhecida a existência de um direito sobre o próprio corpo, procurando definir a sua natureza, recusa a doutrina atribuir-lhe a fisionomia de um direito de propriedade.

Já o havia intuído UlPIANo: dominus membrorum suorum nemo videtur.

IHERING, Tutela da posse, procura reconduzir o conceito do direito sobre o próprio corpo ao conceito geral de pertença jurídica. Objeta, porém, GrISOSTOMI que ou este conceito se confunde com o de propriedade, e então aqui não está exatamente aplicado; ou serve para indicar de modo geral a referência de um determinado direito a um certo sujeito, e então pouco adianta para a dogmática e para o sistema do direito.

Cumpre, ao invés, - conclui - considerar que o direito sobre o próprio corpo não é absolutamente patrimonial, mas pessoal, de caráter especial, que tem por conteúdo a livre disposição do corpo mesmo, com exclusão de qualquer outra pessoa, dentro dos limites assinalados pelo direito positivo (WINDscheID, Pand., I § 40). O direito que cada qual tem sobre o próprio corpo, não se limita à duração da vida; e pode estender a sua eficácia também depois da morte: é o problema da condição jurídica do cadáver.

\section{Direito às Partes Separadas do Corpo: O Sangue. O Sêmen Masculino.}

Mais interessante é a matéria relativa às partes separadas do corpo, do indivíduo com vida.

Insiste ADHERBAL GoNÇALVES em ser fora de dúvida que o ilícito de semelhante cessão só resulta de atentado contra a vida, seus atributos, ou à saúde: 


\begin{abstract}
"Se isto não ocorre, nascerá, então, um direito autônomo de propriedade sobre o que, em algum tempo, integrou o corpo do sujeito, e que, se incorporando na constituição do outro virá a ser tutelado em favor deste, na forma de um direito personalíssimo".
\end{abstract}

Reconheça-se, com DE CUPIS, que o direito às partes separadas do corpo humano é estranho à categoria dos direitos da personalidade, mas proclame-se, ao mesmo passo, com ele, que seu tratamento é tradicionalmente ligado aos direitos da personalidade.

Como exemplo de partes que podem ser separadas do corpo, sem prejuízo sensível para a integridade física, para a saúde, ou para a dignidade humana, ou com afetação maior ou menor do sentido de moral, podem ser citadas: o leite, os cabelos, o material placentário, o sangue, o sêmen masculino.

Não resta dúvida que tão logo essas partes se separem do corpo humano, e poderiam ainda ser acrescentadas as unhas e os dentes, tornam-se "coisas", de propriedade do respectivo titular, independentemente de qualquer ocupação.

É o que encarece o mesmo tratadista:

"A parte separada sai da esfera jurídica estritamente pessoal para entrar imediatamente naquela patrimonial que diz respeito à mesma pessoa, sem passar pela condição intermediária de res nullius."

Exclui, por outro lado, qualquer complemento que, antes da separação, havia sido artificialmente acrescentado ao corpo humano: dentaduras, perucas, membros de madeira ou de outro material. Tais objetos, antes mesmo da separação, entram na esfera jurídica patrimonial do sujeito, e não na pessoal, preexistindo, nestas condições, a propriedade ao desligamento, que não pode produzir a sua aquisição que é preexistente.

O aleitamento por parte de vendedoras de leite, ou amas, sua comercialização através de instituições conhecidas como "Gota de Leite", é admitido como necessidade, e não causa qualquer estranheza de caráter moral.

A venda de cabelos femininos é prática muito usada e foi apanhada, com muita sensibilidade, num conto célebre do escritor norte-americano O'HENRY. 
Mais delicadas as questões relativas à venda do sangue humano e do sêmen masculino.

Principalmente a primeira atingiu um ponto cuja solução não pode mais ser protelada.

Já está perfeitamente organizado a esse respeito um comércio tanto mais escandaloso e torpe porquanto suga $o$ sangue justamente das pessoas menos capacitadas para retirá-lo das veias de seus corpos enfraquecidos pela subnutrição, pelas privações, pela miséria, quando não pelas mais graves moléstias: leshmaniose, tuberculose, diabetes, e que o trocam praticamente por um prato de comida, enfraquecendo assim, inconscientemente, seu já debilitado organismo.

Impressionante reportagem de página inteira de O Estado de S. Paulo, de 06-08-1969, de Francisco Chagas DE MoraIs Filho, sob o título expressivo: "Um Comércio Feito com Sangue", entre outras coisas pouco edificantes refere que pessoas simples e humildes eram convencidas a vender, naquela ocasião, 350 gramas de sangue por $\operatorname{Cr} \$ 8,00$, registrando mesmo o caso de uma família de retirantes persuadida por um agenciador de que, a menos que todos doassem sangue, não poderiam ficar em $\mathrm{S}$. Paulo:

"A ingenuidade a serviço da torpeza". Esse sangue era comprado, pelos hospitais a $\mathrm{Cr} \$ 23$ o frasco e vendido a Cr\$100.00.

A competência para legislar a respeito cabe à Comissão Nacional de Hemoterapia, cuja política tem dois pontos fundamentais :

- O primado da doação voluntária, que deve ser incentivada por todos os modos pelo Poder Público; transfusão.

Noticiava o mesmo jornal, no exemplar de 16-01-1972 o Plano Nacional do Sangue, elaborado pelo prof. PIERRE CAZAL, Diretor do Centro de Transfusão de Sangue da Faculdade de Montpellier, na França, e encaminhado à referida Comissão.

Com base em dados colhidos nos serviços de hemoterapia nas cidades do Rio, Teresópolis, Brasília, Salvador, Belo Horizonte e S. Paulo, foram classificadas em três categorias as entidades que coletam e preparam o sangue humano: os bancos de sangue, que são os mais numerosos; os serviços de coleta, como a Colsan; e os laboratórios industriais, que per- 
tencem à indústria privada. Foi verificada a ausência total de coordenação entre os serviços de hemoterapia inclusive entre os que se localizam na mesma cidade.

O plano aponta vários aspectos positivos nos serviços brasileiros de hemoterapia, principalmente, no que se refere à preparação e imunização do sangue. Mas assinala também diversos pontos negativos, dos quais os mais importantes são: a existência, em cada cidade, de "um número excessivo de entidades que se ocupam em colher, preparar e utilizar o sangue humano"; e o fato de essas entidades recorrerem a doadores remunerados, venderem o sangue a hospitais, acabando assim por formar um comércio lucrativo. Este é o problema principal, pois segundo o professor PIERRE CAZAL, o sangue humano não pode, em qualquer hipótese, ser objeto de comércio.

Os dois problemas - muitas entidades e comércio devem ser resolvidos conjuntamente, diz o plano. Prevê a criação de um Centro de Transfusão de Sangue - CTS que concentraria os serviços de hemoterapia numa área de até 10 mil quilômetros quadrados, destinados a uma população de 300 mil a três milhões de habitantes. E esses centros eliminariam o comércio do sangue.

O plano dispõe que os CTS "fornecerão o sangue gratuitamente a todos os necessitados, sejam quais forem. Além de assegurar a gratuidade absoluta do sangue, o sistema simplificará toda a parte burocrática" - um dos problemas encontrados nos atuais serviços brasileiros.

Deve ser estabelecida uma "tarifa nacional para o sangue", mas cujo preço corresponda exatamente aos custos do serviço de coleta, preparação e distribuição do sangue. Com isto, assegura o plano, "os bancos de sangue não dependerão mais de subvenções e seus recursos se adaptarão automaticamente às suas necessidades".

O Plano foi deixado a.os cuidados do Ministério da Saúde que, segundo membros da Comissão Nacional de Hemoterapia, ainda não encontrou condições ideais para colocá-lo em prática.

Já temos a respeito da matéria algumas leis que vão se acumulando de forma bastante fragmentária e inorgânica.

A fundamental é a Lei n. ${ }^{0} 4.701$ de 28-06-1965, que dispõe sobre a atividade hemoterápica no Brasil e define as bases da Política Nacional do Sangue, cria a Comissão Nacional de Hemoterapia, define sua competência e composição. 
Decreto n. ${ }^{\circ}$ 69.969, de 07-07-1967, por sua vez, regulamenta o registro no cadastro da Comissão Nacional de Hemoterapia dos órgãos executivos da atividade hemoterápica.

Finalmente, o Decreto n. ${ }^{0}$ 61.817, de 01-12-1967 "Veda a exportação de sangue humano, de seus componentes e derivados e fixa critérios de destinação".

Nos termos do art. $3 .^{\circ}$ o sangue humano coletado por punção venosa para fins hemoterápicos nos órgãos executivos a isso autorizados pelo art. $1 .^{\circ}$ do Decreto $\mathrm{n} .^{\circ}$ 60.969, de 07-07-1967, destina-se primordialmente ao emprego em transfusão dentro do respectivo prazo de validade, de acordo com o determinado no item $4 .^{\circ}$ do art. $2 .^{\circ}$ da Lei n. 4.701 de 1965, podendo (art. $\left.4 .^{\circ}\right)$ o sangue de prazo de validade ultrapassado, ou o plasma dele separado, ser cedido à indústria para preparo de derivados.

Autoriza 0 art. $5 .^{\circ}$ a indústria a receber, dos órgãos coletores, a cota de sangue fresco necessária à produção das frações hábeis e o art. seguinte a indústria de derivados de sangue obter dos serviços hospitalares especializados material placentário para servir como matéria-prima, dentro de condições que serão estabelecidas pela Comissão Nacional de Hemoterapia, à qual cabe (art. $7 .^{\circ}$ ) estabelecer as prioridades para a destinação do sangue coletado e de seus componentes e derivados, com a finalidade de manter estoque de reserva para emprego em caso de imperiosa necessidade ou de interesse nacional.

Também os problemas relaciunados ao sêmem masculino já são objeto de preocupação.

O ponto de partida para qualquer estudo é a disponibilidade do corpo da mulher para a inseminação artificial, prática difundida a ponto de existirem em alguns países, bancos de sêmem humano refrigerado:

"O reconhecimento à mulher do direito a ser artificialmente inseminada para satisfazer seus naturais anseios maternais" - pondera ORLANDO GOMES

- "não atenta contra sua personalidade, não obstante o preconceito, muito vivo entre os povos latinos e assimilados, de que rebaixa sua dignidade."

Seu Projeto de Código Civil não enfrentou o problema, "deixando sua solução ao critério dos tribunais, ao estabelecer como limite ao direito de dispor do próprio corpo os bons costumes, para permitir a prática quando evoluir a mentalidade no sentido de que não os fere". 
Remetendo para o Direito de Família o ulterior desenvolvimento de alguns aspectos primordiais da matéria, vejamos se é admissível a disponibilidade do sêmen.

Constituirá crime a sua cessão, gratuita ou remunerada?

Basta correr os olhos pela legislação, verificando não haver qualquer dispositivo que a puna e lembrar o art. $10^{\circ}$ do Código Penal, que não admite a existência de crime sem lei anterior que o defina, para chegar-se à resposta negativa.

Será duvidosa, no entanto, sob o ponto de vista civil, sem texto expresso que a autorize, qualquer transação que tenha como objeto o esperma humano, pelo menos, enquanto não forem vencidos os preconceitos existentes.

Citando BAYON-J. GARCIA: "A mulher casada não pode receber, mais que esperma de seu legítimo marido. $O$ casamento é o canal por onde se deve transmitir a vida humana", sustenta Ellis HERMYdio FigUeIRA, Inegociabilidade da Matéria Orgânica Humana, Transplante de órgãos ou Partes do Corpo. $O$ Sangue, o Leite e o Sêmen, in Justitia, v. 64, 1969, p. 137-152; ser nulo o contrato devido ao objeto ilícito de sua comercialização, considerando o sêmen humano como produto orgânico insuscetível de transação.

Invoca os arts. 145, II, 229 e 231, I do Código Civil, preceituações de ordem pública que não podem ser postergadas, para sustentar que a utilização do sêmen de pessoa que não o marido configuraria ato nulo por ausência de licitude quanto ao objeto, atingindo mesmo esse procedimento os vigamentos da fidelidade conjugal, "derrogando o princípio que institui a legitimidade da família, pela procriação, através do mesmo elo de sangue". loga.

A inseminação homóloga seria admissível, não a heteró-

Mas o fato é que, vários países, enfrentando os graves problemas de toda sorte que a matéria apresenta, admitem a inseminação heteróloga, contando-se por várias dezenas de milhares os já existentes "filhos de provetas".

\section{A Cirurgia e a Lei Penal. O Consentimento do Paciente. A Cirurgia Estética.}

Cada vez se apresentam com maior freqüência problemas relativos à responsabilidade médica decorrente de intervenções cirúrgicas. 
Matéria sem dúvida fundamental, até mesmo para empostação da matéria, há que estabelecer uma separação prévia conforme se cuide de organismos vivos ou de cadáveres.

Lembra CASIMIRo CARAVELli que não é sempre que o médico-cirurgião é chamado para finalidades terapêuticas: sua intervenção pode ter também finalidade eugênica ou simplesmente estética.

A cirurgia estética, que se insere como uma especialidade dentro do conceito da cirurgia plástica, é hoje amplamente aplicada, reconhecendo-se em ambos os casos ser suficientes o consentimento para estabelecer o caráter lícito da operação, e seu grande valor psicológico.

Como diz Luciana, na comédia de PEDro Bloch, "Karla, valeu a pena?":

"Dieta é pretexto. É como cirurgia plástica. A gente faz para curar o que a gente sente e não o que a gente vê. Me dá a impressão de que, dando uma pitangada no rosto e perdendo uns quilos de mim, a angústia também fica mais leve."

Não iria o direito contrariar tendência não generalizada.

Tal intervenção reparadora pode alcançar modalidades as mais diferenciadas, que vão desde o tratamento do envelhecimento precoce, mediante a ablação de porções de pele e esticamento da remanescente de modo a eliminar as rugas mais aparentes, até a correção das "orelhas de abano", a melhoria do perfil do nariz, a redução ou aumento dos volumes mamários, correção da hipospadia, de defeitos naturais ou acidentais, exigindo um acentuado sentido estético de caráter afim aos necessários para a escultura, com seu imanente sentido de harmonia.

Num congresso específico, realizado no mês de fevereiro de 1972, no Jiio de Janeiro, Perseu Ramos, de S. Paulo, colocou em realce o sentido social da plástica estética.

Consignou que as pessoas portadoras de "distorções físicas não decorrentes de doenças" podem tornar-se emocionalmente desequilibradas, voltando ao convívio social e familiar normal quando são reintegradas em padrões físicos aceitáveis.

Invocando definições da oNU, de que a saúde compreende "o bem-estar orgânico e psíquico", o espanhol ULRICH HINDERES manifestou a crença de que uma pessoa, "mesmo não por- 
tadora de doença, não goza de saúde perfeita, caso uma distorção física retire sua tranqüilidade emocional e afetiva." Não existe, então, concluiu, outra solução senão a da cirurgia plástica estética.

Quando mal sucedida, poderá, no entanto, trazer inconvenientes piores do que os anteriores, com possível surto de ações de indenização.

Generalizando os conceitos emitidos por Adolfo PRUNotTo, La Ley Penal y los Transplantes de Organos, in Revista del Colegio de Abogados de Rosário, a. I, n. ${ }^{\circ}$, agosto de 1969, p. 41-49, também podemos repetir que princípios fundamentais que entram em jogo na solução das diferentes hipóteses são ministrados, por um lado, pelo conceito técnico-jurídico do delito, pela doutrina do consentimento do interessado, pelas normas que aludem ao exercício de um direito e ao cumprimento de um dever - que concorrem para justificar a atividade médica - e pelas definições legais dos delitos de homicídio e lesões, disposições estas últimas que podem eventualmente captar a conduta médica, e, por outro lado, pelas regras legais que aludem à vida, à morte e ao cadáver, contidas em outros ramos do direito.

Esse mesmo autor aborda, pouco adiante, elemento de importância fundamental na matéria: o do consentimento do interessado, fazendo ver que, naqueles casos em que a figura delituosa inclui em sua definição que a atuação do agente deve realizar-se contra a vontade do sujeito passivo titular do bem jurídico que se protege, o concurso do consentimento do interessado acarreta como conseqüência a atipicidade da conduta.

Será diferente a situação quando o tipo penal não alude expressamente à vontade do sujeito titular do bem jurídico, e, conseqüentemente, a ação é objetivamente típica.

Lembra que a doutrina admitiu o consentimento do interessado como causa excludente da antijuridicidade da ação, mas encarece a dissensão no que diz respeito a quais bens assume transcendência justificante a presença dessa vontade consentidora.

Manifesta que esta terá transcendência para determinar a não ilicitude de uma conduta típica quando esteja em jogo somente um direito subjetivo, mas não naqueles casos em que, conjuntamente, tutela-se um interesse social da coletividade, de forma direta. 
Bem se percebe a transcendência da importância desse elemento no que diz respeito à mutilação de órgãos, para finalidades diversas.

\section{Correção de Malformações Sexuais.}

Qual seja o sexo de uma pessoa. logo se vê. Com raras exceções, além de pela conformação corporal, pela postura, pela voz, pelo comportamento.

Mas ocorrem casos de más configurações dos órgãos em que somente um exame realizado por peritos pode tirar as dúvidas a respeito do verdadeiro sexo da pessoa, envolvendo delicados problemas de preservação da própria intimidade.

Muitas vezes apenas uma intervenção cirúrgica corretora poderá definir o tipo que se apresenta com características dominantes, nos casos, por exemplo, de hermafroditismo (que sempre provocam confusão nas pessoas, cuja indefinição somática, acaba por explodir numa grande indecisão psíquica).

Explicou Antonio Gentil Martins, no xil Congresso Latino-Americano e IX Congresso Brasileiro de Cirurgia Plástica encerrado no dia 04-02-1972 em S. Paulo, há sempre um dos órgãos genitais mais desenvolvidos, consistindo a operação na correção do órgão que apresente melhores condições de recuperação, e extração do mais deficiente: em geral um clitoris muito desenvolvido, cujo tamanho é reduzido, procedendo-se à abertura do sino uro-genital e à amputação do pênis pouco desenvolvido, atribuindo a neovaginoplastia dimensões corretas à vagina.

Quando propende o sexo masculino, o pênis hiplopásico, encurvado "em gatilho", é corrigido pela ortofalplastia e neurotraplastia. Ocorrendo ausência de testículos, introduz-se próteses testiculares de silicone nas bolsas escrotais, em tamanho e peso correspondentes à idade do interessado.

Isso tudo precedido de cuidadosa análise do histórico da vida do mesmo, que pode proporcionar valiosos subsídios auxiliares na definição do sexo, bem como do estudo dos seus cromossomos e hormônios, para se determinar o sexo preponderante, sem exclusão de um rigoroso tratamento psiquiátrico, e seguido por outras cirurgias destinadas a dar a conformação dos genitais e dos caracteres sexuais secundários, reintegra-se o paciente em condições para uma vida sexual normal.

Tendem a ser cada vez numerosas as histórias como as de Omar Agnaldo do NASCIMENTo, de 31 anos que se submeteu 
a delicada operação para, depois de ter vivido 26 anos como Maria Olívia, desenvolver seus caracteres sexuais masculinos, para casar-se, no dia 20-07-1975, no município de Souza, Paraíba, com Nelcina Casimiro de Souza, da qual pretende ter 11 filhos.

A matéria teve de ser abordada num caso de pedido de retificação de registro de nascimento no que diz respeito ao sexo e ao prenome do suplicante, pelo Juiz de Direito de Mairiporã, em sentença noticiada pelo $O$ Estado de S. Paulo de 25-01-1976, confirmada pela Segunda Câmara Cível do Tribunal de Justiça de S. Paulo (apelação n. ${ }^{\circ}$ 235.341).

Acentuou o magistrado, ANTonio de PAdUA FerRaz NoGUEIRA, que, além dos hábitos, comportamento e conformação corporal - para a conceituação da mulher é necessária a existência, no interior do corpo, dos órgãos genitais femininos: "dois ovários; duas trompas, que conectam com o útero; a vagina, os genitais externos; e algumas glândulas acessórias" e "seios ou glândulas mamárias" que "são considerados por alguns como partes do sistema reprodutor".

Por outro lado, para a conceituação do homem - além da presença dos hábitos, comportamento e da peculiar conformação corporal - é indispensável a existência, situados parcialmente no interior do corpo e parcialmente no exterior do mesmo, dos seguintes órgãos genitais masculinos: "testículos (que se chamam também gônadas), espedídimos, cordões espermáticos; próstata, vesículas seminais; uretra; pênis e glândulas acessórias".

No caso os exames médicos, confirmados pela perícia, demonstravam encontrar-se, o interessado com "ausência de órgãos genitais femininos", apresentando tipo constitucional masculino, presentes os órgãos correspondentes, embora "apresentando pênis com malformação congênita (hipospadia), malformação congênita e testículos ligeiramente hipoplásticos:

"Em conseqüência, é exato que o interessado terá ausência de barba (ou escassa) e outros caracteres secundários, diante da falta de células Leydig, decorrente da deficiência do hormônio sexual masculino encarregado da fabricação dessas células, dentre outras. Outrossim, em decorrência dos seus testículos não produzirem "espermatogênese, não tem condições de procriar. Além disso, por ser portador de malformação congênita do pênis, dificilmente poderá ter conjunção-carnal". 
A esterilidade, que resulta na impotência "generandi" é comumente encontrada no sexo masculino e, diante do direito, não desfigura esse genotipo - não constituindo mesmo óbice para o casamento.

O mesmo se podia dizer, em parte, quanto à concepção jurídica sobre os homens com impotência — "couendi" (funcional ou instrumental), a exemplo da "hipospadia" — que é o caso do interessado. Não deixam de ser do sexo masculino apesar do impedimento para o matrimônio, quando se tratar de "hipospadia irremediável". Na espécie, segundo os subscritores do laudo, essa "hipospadia" (na qual a uretra se abre na parede inferior do corpo do pênis, em vez de fazê-lo na extremidade livre do mesmo), parece ser remediável, desde que se submeta "a tratamento hormonal", quando haverá possibilidade de condições para as relações sexuais, "dependendo do resultado desses tratamentos".

\section{Castração. Esterilização.}

Por exigências eugênicas pode ser necessária a castração e a esterilização, lícitas caso o paciente esteja afetado por doença incurável e transmissível como no caso de sifilítico para quem se torne indispensável a intervenção para não dar origem a degenerados e raquíticos.

Segundo a lenda, a castração foi introduzida pela formosa Semiramis, rainha assíria fundadora de Nínive e Babilônia, para evitar heranças mórbidas, daí se espraiando para todo o Oriente, Grécia e Roma.

É o que lembra JosÉ BeLBEY, La Esterilizacion Humana por el Estado, in Archivos de Medicina Legal, Buenos Aires, 1935, n. ${ }^{\circ} 1$, p. 10-17, fazendo ver ter ocorrido ainda com fins religiosos, sexuais, penais, artísticos, dogmáticos, eugênicos, no decorrer de toda a história da humanidade.

Além da famosa lei racista alemã de 14-07-1933 de "esterilização dos anormais", desde 1907 começa a aplicar-se no Estado de Indiana, e atualmente na maioria dos Estados Unidos da América do Norte, em alguns, leis de esterilização de anormais, em outros, de delinqüentes, e nos demais, de ambos.

$\mathrm{Na}$ Europa a primeira lei foi promulgada em 1929, no cantão de Vaud, Suíça. Desse mesmo ano é a lei de esterilização pelo Estado da Dinamarca, seguindo-se a Suécia. 
Calculava-se, em abril de 1971, serem esterilizados diariamente quarenta ingleses, trezentos americanos e dois mil indianos. da India.

Em nenhum outro país a matéria assumiu as proporções

As autoridades, preocupadas com os índices alarmantes de fome e de miséria, com 520 milhões disputando uma porção diária de 200 gramas de arroz por pessoa, nascendo diariamente 35.000 indianos, ritmo capaz de dobrar a população em vinte anos, começaram por oferecer um rádio de pilha, muito apreciado, ou seu equivalente em rúpias para cidadão esterilizado.

Não alcançando a campanha o êxito esperado, passou o governo a realizá-la compulsoriamente, chegando a obrigar os funcionários públicos e professores a indicar cinco "voluntários" cada um, sob pena de terem suspensos seus vencimentos, quando não demitidos sumariamente.

O pavor provocado pelos sete milhões de esterilizações efetuadas no ano de 1976 levou milhares de pessoas a se refugiarem nas florestas, transformando-se num problema político tão grave que contribuiu decisivamente para a derrota de Indira Gandhi nas eleições de março de 1977.

A matéria vai assumindo importância cada vez maior à medida que aumenta a prevenção contra as pílulas anticoncepcionais, e que vão se aperfeiçoando as técnicas de vasectomia, já permitindo cortar e depois emendar o canal deferente através de uma espécie de plug de vedação, que pode ser retirado, quando o paciente quiser voltar a ter filhos.

Podem surgir casos pitorescos, como o registrado nos Estados Unidos:

Um paciente americano fez a vasectomia sem comunicar à mulher. Meses mais tarde, recebeu, com grande susto, esta notícia:

- Henry, eu estou grávida!

Expulsou imediatamente a mulher de casa e iniciou o processo de divórcio, provando ter feito a vasectomia. Como a mulher insistia na fidelidade, seu advogado requereu uma junta de especialistas. Depois dos exames, o mistério foi resolvido: um dos canais deferentes tornara-se permeável permitindo a passagem de espermatozoides e conseqüentemente a gravidez da mulher.

Qual a situação no Brasil? 
Tanto a esterilização do homem, como a "ligação das trompas" da mulher são proibidas pelo Decreto n. ${ }^{\circ} 20.931$, de 11-01-1932, que regula o exercício da medicina: art. 16.

Isso não impediu que o número de homens esterilizados no Brasil em 1969, através de operações clandestinas, fosse de 500 , passando em 1970, a 500, com um aumento, apenas de $50 \%$ num ano.

Explica-se a maioria dessas operações sub-reptícias considerando mais o lado humano do que o legal do problema: se a mulher não pode ter mais filhos, nem usar as pílulas, nem se submeter a qualquer outro método, a única solução passa a ser esterilização.

\section{Transexualismo e Operação Objetivando "Mudança de Sexo".}

A determinação do sexo não decorre exclusivamente da reunião, no mesmo indivíduo, dos seus caracteres orgânicos admitidos pela medicina para o reconhecimento de um indivíduo como pertencente a um ou outro sexo: não se verificando a concordância, ocorre o hermafroditismo.

Odon Ramos Maranhão, Manual de Sexologia MédicoLegal, S. Paulo, Rev. dos Tribunais, 1972, encarece não se poder mais considerar o conceito de sexo fora de uma apreciação plurivetorial, resultante como é de um equilíbrio de diferentes fatores: genéticos, somáticos, psicológicos e sociais.

Verificam-se, com efeito, casos de indivíduos que, reúnem, no corpo, todos os caracteres orgânicos de um determinado sexo, enquanto todo o seu psiquismo propende, irresistivelmente, para o oposto.

Teremos então hipóteses de travestis, ou fetichistas, que sentem necessidade de usar vestuário, atitudes e complementos do sexo oposto, ostentando sua aparência; homossexuais, que só se realizam com pessoas de seu próprio sexo, e transexuais, que têm toda a disposição psíquica e afetiva do sexo oposto, mas não se conformam nem se conciliam com a sua condição.

Por isso o comportamento destes é diferente: repudiam o sexo para o qual se apresentam instrumentalmente dotados não apenas pelo seu comportamento, mas, também, biologicamente, procurando, quando o tratamento clínico não seja suficiente, o recurso extremo da cirurgia, a fim de viver regularmente como 
integrantes do sexo psíquico, ao qual sentem pertencer, pro. curando assim conciliar físico e espírito.

Este tipo de pessoas foi detectado com maior nitidez em 1966, quando o centro médico da Johns Hopkins University passou a efetuar "mudanças cirúrgicas de sexo", realizando nos seis anos seguintes 32 operações, nove das quais "transformaram" mulheres em homens.

A cirurgia, é claro, resulta diferente nos homens e nas mulheres. Nestas consiste em remover os seios, extirpar, por meio de histerectomia, o útero, e aproveitar o tecido clitóris para fazer um arremedo de pênis, colocando, mediante prótese, testículos.

Naqueles, amputados seus órgãos sexuais, é aproveitada a pele sensível do pênis para a feitura de uma vagina artificial, aumentando-se os seios.

As operações, com variante próprias a cada caso, são complementadas com a ministração de hormônios sexuais: testosterona para os que passam a ser considerados homens, e estrógenos para as mulheres reconstruídas, destinados a estimular as características secundárias do sexo adotado.

Procuram, assim, as "mulheres aprisionadas em corpo de homem", ou vice-versa, pôr fim aos conflitos psicológicos e sociais de que são vítimas, evitando, muitas vezes, o suicídio ou a degradação.

No XV Congresso Brasileiro de Urologia, realizado em novembro de 1975, o cirurgião plástico Roberto Farina, docente da Escola Paulista de Medicina, expondo uma tese, exibiu um filme de sua cirurgia de reversão sexual realizado em 1971, anunciando que a havia executado em nove pacientes masculinos. Entre os 50 mais que havia um ano estavam fazendo testes psicológicos, psiquiátricos, genéticos e hormonais preparatórios à operação, encontravam-se duas mulheres que pretendiam adaptar seus corpos ao sexo psicológico masculino.

Dentre as muitas reações provocadas pela comunicação, uma foi inesperada e rumorosa: ao tomar dela conhecimento pela imprensa, o Ministério Público de S. Paulo, através do Promotor Messias Paiva, da $17 .^{a}$ Vara Criminal da Capital, denunciou o cirurgião, em agosto de 1976, como incurso nas penas do art. 129, § 2.0 inciso III do Código Penal, por ter cometido lesões corporais de natureza grave, causando perda ou inutilização de membro, sentido, ou função, cominadas com pena de reclusão de dois até oito anos. 
A denúncia dizia respeito à operação realizada num dia de dezembro de 1971, nas dependências do Hospital Oswaldo Cruz, consistente na ablação dos órgãos sexuais, ou seja, falo, escroto e testículos, e abertura no períneo, mediante incisão, de uma fenda, à imitação de vulva postiça, artificial, para onde transplantou a uretra, ofendendo, assim, a integridade física de Waldir Nogueira, já que, daquele ato cirúrgico, resultou, para o ofendido, a perda irreparável dos referidos órgãos e inutilização de suas respectivas funções.

Waldir, que havia obtido na época autorização da Vara dos Registros Públicos, posteriormente revogada, para mudar seu nome para Waldirene, alegava "viver numa incerteza que lhe dificultava até mesmo as atividades de um ser humano, não podendo registrar-se para trabalhar nem como homem nem como mulher".

Mas a denúncia entendeu que era, sem dúvida, indivíduo do sexo masculino, posto que portador de órgãos genitais externos masculinos, que não trazia quaisquer traços do pretendido hermafroditismo ou mesmo pseudo-hermafroditismo e o indiciado sabia, de antemão que jamais poderia transformá-lo em pessoa do sexo feminino porque não conseguiria implantar, como não implantou, os órgãos genitais internos femininos, como o útero, ovário e anexos, órgãos estes destinados a conceber e dar à luz, os quais o ofendido jamais teve, nem tem.

Além de criar, para o ofendido, graves problemas no seu relacionamento social, transformando-o, através daquela ilícita cirurgia, num verdadeiro eunuco, o indiciado ainda pretendia criar, com ela, condições favoráveis para uniões matrimoniais espúrias, que o Poder Judiciário, teria, fatalmente, que decretar nulas toda vez que o cônjuge varão assim o pedir, pretextanto erro essencial quanto à pessoa do outro.

Estará certa a orientação? Será condenável a ablação dos órgãos genitais de uma pessoa, quando não se manifeste nenhuma malformação exterior, para que possa melhor aparentar ser do sexo oposto?

Quando se trate de uma anomalia psíquica, não visível, não terá o interessado o direito de dispor, como entender, das partes do seu próprio corpo?

Divergem profundamente as opiniões.

O Conselho Regional de Medicina de S. Paulo já teve ocasião de manifestar-se contra a licitude dessas intervenções cirúrgicas. 
O Conselho Federal de Medicina, pela unanimidade de seus membros, ao examinar caso que lhe fora encaminhado pelo Conselho Regional de Santa Catarina, concluiu tratar-se exclusivamente de cirurgia mutiladora, jamais restauradora do ponto de vista psicosocial, não the reconhecendo qualquer finalidade terapêutica, decisão essa encaminhada aos Conselhos Regionais e às escolas médicas, para conhecimento e cumprimento.

No mesmo sentido, depois de uma minuciosa resenha dos elementos relativos à sexualidade típica e à ambígüa, dos caracteres sexuais normais, das influências endócrinas extragonadais, do hermafrodismo e do pseudoermafrodismo e das formas intersexuais menores, inclusive estabelecendo distinção entre sexo biológico e sexo legal, a lição de VICENZo MARIo PALMIERI, Sesso (Diagnosi e Mutamento di Utet), in Novissimo Digesto Italiano, Turim, v. XVII, 1970 , p. 226-234, que considera a tomada de posição da jurisprudência italiana conforme "às exigências jurídicas e éticas da personalidade", permitindo-lhe considerar ilícitas, ocasionalmente mesmo delituosas, as modificações arbitrárias dos órgãos copulatórios, em virtude de uma aptidão (ativa ou passiva) postiça à compenetração.

O referido acórdão unânime da Segunda Câmara Civil do Tribunal de Justiça de S. Paulo de 01-02-1972 (Rev. dos Tribunais, v. 444-94), sem se pronunciar a respeito, prestigiou parecer do Procurador da Justiça que considerou o ato cirúrgico desaconselhado, e talvez mesmo criminoso, de caráter meramente mutilatório, a tal ponto que o postulante, ao que afirmara, teve necessidade de procurar médico em outro país, para a prática, pois, com bons motivos de ordem deontológica e penal, os nossos facultativos se haviam escusado da realização da referida intervenção cirúrgica.

Também a C. 5. ${ }^{\text {a }}$ Câmara do mesmo Tribunal, em acórdão referido pelo $O$ Estado de $S$. Paulo de 18-01-1975, na apelação cível 247.425 chegou a idêntica conclusão.

Considerou o relator, Des. CoElho DE PAULA "lamentável" a situação criada pela operação efetuada, qualificando de erro "quiçá até criminoso", o ato cirúrgico que atribuiu ao paciente sexo que, na realidade não tinha, nem poderá ter jamais, e que poderá levar pessoas a se unirem, em matrimônio, quando um dos fins do enlace, a procriação, jamais poderá ser atingido.

Tivesse tido o interessado tratamento adequado, em tempo mais remoto, e tudo faz crer que poderia ter chegado a ser homem praticamente normal. 
São numerosos, como se vê, e dos mais abalizados, os que consideram conflitantes tais operações, ao arrepio da ética médica e com infração de claros dispositivos penais, levando mesmo à degradação da espécie.

Não mudariam os pacientes de sexo, não poderiam casar validamente, pois é essencial a diferença de sexos, não poderiam obter a correção de seu registro civil.

O que torna mais apaixonante a discussão é que a atitude do médico não foi inconsiderada. Antes de iniciar essas operações, passou vários anos estudando o assunto sob o ponto de vista legal, e a situação do paciente que sofre a "mudança de sexo".

Numa entrevista publicada pela imprensa de 28-12-1975 faz ver que não é a única operação que ocasiona, licitamente, a perda de órgãos ou função:

"Os neurocirurgiōes, nos casos de dores incontroláveis, encefalopatias com componente agressivo e mesmo na esquizofrenia, não fazem ou faziam lobotomias e até lobectomias? E o que não dizer da cirurgia estero-táxica com emprego da fria cirurgia e bisturi elétrico provocando a destruição de zonas seletivas cerebrais para o tratamento de mal de Parkinson, epilepsia temporal focal, etc? $\mathrm{E}$ os transplantes renais intervivos? E a extirpação dos testículos normais para o tratamento de um câncer da próstata? Não existem aqui, também, lesões corporais?".

Todos esses casos, analisados pela letra do texto da lei, seriam incriminados.

Mas não podem ser considerados sob esse ponto de vista, pois o aludido dispositivo do Código Penal refere-se exclusivamente a lesões corporais graves provocadas intencionalmente, dolosamente, na área dos delinqüentes comuns.

Enquadrá-lo nesse contexto transcenderia ao bom senso comum: o jurista não pode e não deve ater-se à letra ou forma do texto da lei, mas sim ao seu espírito. Pela simples letra do texto da lei, todos os cirurgiões se enquadrariam como criminosos.

Considera que o sexo mais importante é o psicológico. Por isso não concorda com os que sustentam que só é mulher aquele ser capaz de conceber e dar à luz (no caso do transexual mas- 
culino, que é submetido à cirurgia, ele se tornaria mulher, mas sem condições de procriar). Se essa posição fosse correta, a mulher estéril não seria mulher. "De nada adianta uma genitalia masculina invejável se esta, por força de mente feminina, não é capaz de atuar ou desempenhar as suas funções".

O transexual apresenta um perfil psicológico totalmente diferente do homossexual. Enquanto ele nasce transexual (o seu comportamento começa a se manifestar a partir do terceiro ano de idade) o homossexual se torna homossexual manifestando o conflito entre os padrões psicológicos e os seus caracteres sexuais orgânicos durante a puberdade.

0 professor Farina afirma ser como o soldado: executa as ordens do general. No caso, o psiquiatra, o psicólogo, o geneticista e o endocrinologista que decidam os pacientes que devem ser operados:

"Em vez de incriminar os médicos pela prática da operação de reajustamento sexual, os juristas deveriam disciplinar a matéria da legislação dos casos operados, (mudança de assento ou registro, problemas ligados à aposentadoria, serviço militar e uma série de implicações decorrentes) e deixar a critério da classe médica esse problema de cunho altamente filosófico e científico".

Nos países onde também são realizadas operações de reversão sexual não existem sanções penais ou legais. Em alguns estados dos Estados Unidos, como no Arizona, Louisiana, Illinois e Mississipi, a pessoa que tem o seu sexo mudado recebe uma nova certidão de nascimento. Em outros, como em Nova York, apenas é corrigida a certidão anterior ou original onde, ao lado do nome e do sexo anterior constam o nome e o sexo atuais.

Apenas as pessoas maiores de 21 anos podem ser submetidas à operação de reajustamento sexual. No caso paulista, o paciente assina dois documentos: um isentando o cirurgião de qualquer aspecto negativo da intervenção ou um possível arrependimento posterior, o outro comprometendo-se a não dar entrevista e muito menos citar o nome do médico.

Além disso os especialistas afirmam que o transexual assume o seu papel feminino (ou masculino) na sociedade apesar de sua genitalia ser masculina (ou feminina). Ele se revolta contra os seus caracteres sexuais primários (órgãos sexuais) e secundários. 
O transexual masculino não aceita relações sexuais com mulheres porque, tendo uma mente feminina, acha que estaria praticando um ato homossexual: "e quando compelido a proceder como homem sofre torturas que facilitam o "stress" e, submetido a condições estressantes, abrem-se as portas para as neuroses e psicoses que levam alguns deles ao suicídio. Além disso, o transexual masculino usa roupas femininas porque se sente mais a vontade. Ao contrário do homossexual não experimenta excitação. Sai pouco de casa, onde se dedica aos afazeres femininos. A psicoterapia tradicional, no caso de transexuais, é considerada inoperante.

Ele aceita mudar muita coisa, menos o seu sexo psicológico. P.or isso, "apresenta uma determinação obsessivo-compulsiva para se submeter à operação. Na verdade, o sexo para ele é secundário e os seus órgãos genitais não são o centro do erotimo. Para os homossexuais, a situação é oposta. Os transexuais masculinos não são efeminados e sim femininos, enquanto os homossexuais são efeminados e não femininos".

A diferença entre o transexual e o homossexual é muito grande. A equipe da qual participa o professor Farina já havia recebido alguns homossexuais. Mas durante o tratamento pré-operatório, que leva de um a dois anos, eliminou-os porque só o transexual pode ser submetido à cirurgia.

Sem embargo daquelas tão respeitáveis opiniões em contrário, não faltam também, na verdade, as dos que entendem não estarmos diante de um ato que possa ser caracterizado como crime.

Assim, Adolfo PRUNotTo obtempera que mesmo a afirmação de que a conduta resulte típica não leva fatalmente a concluir seja ela ilícita ou antijurídica.

Mesmo a prova de que nos encontramos frente a uma ação típica e antijurídica não importa incluir que estamos frente a um delito:

"Esa comprobación sólo significa haber agotado el análisis de una faz del hecho, la objetiva. Para llegar a la conclusión de que una acción típica y antijurídica configura un delito resulta legalmente imperativo considerar también la fase espiritual del acto o sea dejar establecida la actitud subjetiva real del agente frente al resultado ilícito que causó con su acción - culpabilidad. Nullum crimen, nulla poena sine culpa." 
Prossegue demonstrando que é a análise da atitude subjetiva real do agente que vai patentear se ele quis diretamente o resultado ilícito que produziu - dolo - ou se esse resultado antijurídico foi causado unicamente por sua negligência ou imprudência - culpa.

Quando qualquer desses pressupostos subjetivos tenha acompanhado a ação típica e antijurídica que se executou, diremos que o agente agiu com culpabilidade, dolosa ou culposa, conforme o caso.

Pietro PERLINGIERI acentua não ser na verdade relevante para o direito somente o sexo psicológico-social, ou o biológico, mas qualquer elemento que concorra à sua complexa definição, uma vez que pode, para finalidades particulares, ter relevo jurídico, embora:

"per la maggior parte delle ipotesi é il profilo psicologico, ancor piú di quello strutturale e biologico, a prevalere come criterio qualificante la disciplina dei rapporti."

Justifica, nestas condições, a mudança de sexo não como expressão de livre e arbitrária escolha do interessado, mas como conseqüência de terapias e de intervenções cirúrgicas voltadas a secundar uma tendência natural, ou para evitar efeitos negativos sobre a saúde, como no exemplo de uma neurose grave, ou sobre o comportamento da pessoa.

$\mathrm{Na}$ hipótese de qualquer alternativa do ponto de vista objetivo apresentar riscos análogos e inconvenientes equivalentes, a escolha poderá ser entregue à mera vontade do interessado, que poderia mesmo, se o "seu" caso não apresenta os extremos da necessidade da escolha, decidir de conservar o estado de "intersexo".

Insiste em que:

"A intervenção sobre a pessoa para mudança de sexo é legítima desde que correspondente ao interesse da pessoa, que assim é não porque correspondente ao capricho do mesmo, mas porque constitui o resultado da avaliação objetiva das suas condições. Seria portanto antijurídico o comportatamento do médico que interviesse para provocar uma modificação numa pessoa de sexo unívoco e completamente sã." 
A matéria somente adquirirá definição quando for emanada alguma norma legislativa a respeito.

Confiamos em que venha a solucionar o problema reconhecendo, em caráter excepcional, e mediante todas as cautelas, a permissibilidade.

Vários precedentes poderiam ser invocados.

Nos Estados Unidos da América do Norte, tais operações são praticadas sem grandes preocupações de natureza legalista, ficando, é lógico, cada qual responsável pelos atos praticados.

Na Argentina o cirurgião Francisco Defazio, preso no ano de 1965 sob acusação de ter causado "lesões corporais gravíssimas" em conseqüência de operações similares, foi absolvido pela Câmara Criminal de Buenos Aires em data de 30-12-1969.

Temos notícia de que um projeto de lei apresentado ao Parlamento de Estocolmo objetiva permitir aos suecos trocar, em caso de necessidade, oficialmente de nome e de sexo.

Toda pessoa maior de 18 anos de idade teria direito a estabelecer, através de um documento, que pertence ao sexo oposto ao que lhe foi atribuído oficialmente ao nascer, se estiver convencida de que, desde sua infância, seu comportamento está mais conforme com o outro sexo, sob condição que os interessados sejam solteiros e estéreis, natural ou artificialmente.

\section{Retirada de Partes do Corpo Humano Vivo Para Transplantes.}

Problemas fundamentais continuam sendo os que dizem respeito ao enxerto "seção de uma porção do organismo, próprio ou organismo alheio, com fins estéticos e terapêuticos, sem exercício de função autônoma" e ao transplante "amputação ou ablação de um órgão, com função própria, de um organismo para instalar-se em outro, a fim de exercer neste as mesmas funções que o anterior" (JOSÉ ToDolí).

SÃo Tomás DE Aquino já admitia, na Suma Teológica, o transplante de partes extraídas de animais. Justificava com o princípio de que as coisas imperfeitas subsistem por causa das coisas perfeitas. Por desígnio da vontade Divina era lícito o uso das plantas em favor dos animais, e dos animais a favor do homem, com exceção das glandulas gerativas, porque a operação resultaria degenerativa da espécie e atentatória ao direito natural e à moral. 
Bem mais delicado, como se vê, o aproveitamento de partes do corpo de um ser humano vivo, a enfrentar problemas de ordem moral, religiosa, ética e jurídica.

Vencido o período de discussões, foi admitido pela lei italiana de 03-04-1957, cujo regulamento, de 1961, indica quais as partes do cadáver humano que podem ser retiradas e transplantadas: bulbo ocular, suas partes e anexos; ossos e superfícies articulares; músculos e tendões; vasos sangüíneos; sangue; nervos; pele, medula óssea; aponevrose; dura-mater.

Entre nós, a Lei n. ${ }^{\circ} 4280$, de 06-11-1963, dispôs "sobre a extirpação de órgão ou tecido de pessoa falecida", tendo sido revogada pela Lei n. ${ }^{\circ} 5479$, de 10-08-1968, que "dispõe sobre a retirada e transplante dos tecidos, órgãos e partes de cadáver para finalidade terapêutica, e dá outras providências".

Mas o título não alcança todo o conteúdo, uma vez que permite "à pessoa maior e capaz dispor de órgãos e partes do próprio corpo vivo, para fins humanitários e terapêuticos"

O mais grave de todos os problemas diz respeito, naquele caso, à verificação da morte do organismo do "doador".

Cumpre, em seguida, averiguar se a disponibilidade diz respeito a qualquer parte do corpo, ou se existe alguma restrição.

A Lei n. ${ }^{\circ} 5479$ só traz indicações com relação ao organismo vivo, art. 10:

"§ $10^{\circ}$ - A autorização do disponente deverá especificar o tecido, ou órgão, ou a parte objeto da retirada.

$\S 2 .^{\circ}$ - Só é possível a retirada, a que se refere este artigo quando se tratar de órgãos duplos ou tecidos, vísceras ou partes e desde que não impliquem em prejuízo ou mutilação grave para o disponente e corresponda a uma necessidade terapêutica, comprovadamente indispensável, para 0 paciente receptor".

Outras limitações não existem, e nenhuma é formulada com relação à retirada de órgãos do cadáver.

Mas a referência contida na parte final do último parágrafo deixa perfeitamente clara a aplicabilidade, ao nosso 
texto, da observação de ADRIANo DE CUPIS, p. 111, relativa à não proibição do consentimento ao transplante de porções de pele ou mesmo de partes de maior importância:

"Se o organismo, que sofre a retirada, não perde a possibilidade de se reconstituir com a recomposição dos tecidos lesados, o consentimento deve entender-se lícito e válido. De fato, além de não se verificar diminuição permanente da integridade física, não se verifica nem mesmo contrariedade à moral (bons costumes) : esta não é ofendida por operações que alcançam o benefício da saúde do terceiro sem prejuízo duradouro do sujeito sobre cujo corpo são executadas".

No que diz respeito à operação cirúrgica objetivando realizar um interesse estranho à pessoa em cujo corpo seja executada, a bem da saúde de um terceiro, ou o progresso científico, em tese, tais operações seriam ilícitas, uma vez que ao prejuízo sofrido não corresponde a futura eventualidade de uma vantagem para a saúde da mesma pessoa.

Como, porém, o fato da operação objetivar um interesse estranho à pessoa do paciente, não é suficiente, por si só, para excluir a validade do consentimento, ADRIANO DE CUPIS, estabelece uma distinção:

"Não é proibido o consentimento ao transplante de porções de pele ou mesmo de partes do corpo de maior importância. Se o organismo, que sofre a extirpação, não perde a possibilidade de reconstituir-se com a recomposição dos tecidos lesados, o consentimento deve entender-se lícito e válido"

O Hospital das Clínicas de S. Paulo conta com um Banco de Peles, que, todavia, passa periodicamente por situações precárias por falta absoluta de material.

A tal ponto que os nove especialistas do Setor de Queimados são levados a aplicar pele de porco como curativo biológico, substituída logo que o estoque esteja suprido. Para contornar a dificuldade, estão pesquisando uma pele sintética, que libertará os transplantes da dependência de retiradas de partes da pele de cadáveres, que não têm recursos técnicos adequados para manter viva além de seis horas.

Segundo informação de ARY do CARmo Russo, divulgada pela imprensa de 09-06-1973, a disponibilidade de peles está 
muito ligada ao restabelecimento do paciente com queimaduras graves. Isto porque nestes casos não deve ser aplicada nenhuma droga imuno-repressora contra as rejeições, devido ao inconveniente de minar as defesas do organismo contra bacterias e infecções, muito comuns nas queimaduras. A mudança das peles transplantadas deve, então, ser bem pouco espaçada, para que o paciente, já debilitado com os ferimentos, não precise iniciar o processo de rejeição. A troca de peles deverá dar-se, no mínimo de cinco em cinco dias, até que o organismo possa recuperar-se espontaneamente.

A função dos transplantes - que em termos de peles pode ser entendida mais como um curativo - é evitar perdas de sangue, plasma e sais minerais. Quando a.s condições gerais do paciente melhoram e ele já pode se recuperar sozinho, a função dos transplantes termina e as peles enxertadas são retiradas.

"O enxerto é uma peça provisória funciona como salva-vidas, durante uma semana até 40 dias, ou no máximo, 80 dias".

Como a carência de doações de peles é grande, muitas vezes os próprios parentes das pessoas queimadas se oferecem para fazer a doação, o que aumenta o trabalho dos médicos e a ocupação dos leitos hospitalares.

Em certos casos o próprio paciente é o doador, mas isto não é possível quando as queimaduras atingem mais de 30 por cento do corpo. As doações testamentárias não têm dado resultados porque como a pele permanece viva apenas até 6 horas após a morte e o testamento ou as instruções do morto são, geralmente, conhecidos depois deste prazo, as doações tornam-se inúteis.

São os próprios parentes dos mortos que impedem que seus corpos sejam aproveitados.

"As peles dos transplantes devem pertencer a quem gozou de boa saúde, como, por exemplo, dos mortos por acidentes. Mas, nos casos de morte súbita, os parentes estão demasiadamente chocados para ouvir explicações que esclarecem que a doação de peles não é uma profanação do cadáver"

Por esta dificuldade crônica em adquirir peles, os especialistas do Hospital das Clínicas ainda não utilizam os métodos 
mais avançados de conservação, como o congelamento e a manutenção em glicerol, que permite sejam utilizadas até 400 dias depois de seu recolhimento.

Será diferente a solução no que diz respeito ao transplante de algumas partes especiais do corpo, como a das glândulas genitais, cuja retirada produz uma diminuição permanente da integridade física, que vai além de um alcance meramente anatômico.

A matéria era amplamente discutida, há alguns decênios, quando estava em plena voga o sistema WoroNOFF, que exigia que o cirurgião procedesse primeiro à extirpação de uma das glândulas sexuais cedida voluntáriamente pelo cedente, e, em seguida, ao seu transplante na pessoa do cessionário.

Sem discutir a duvidosa utilidade da operação mostra Casimiro Caravelli, Médico, in Dizionário Prático del Diritto Privato, Milão, Vallardi, v. III, parte III, 1936, p. 975, a divergência que então se notava entre os doutrinadores: para GRISPIGNI e DEL VECCHIO, a cessão é perfeitamente lícita, porque justificada pelo consentimento, da mesma forma que a extração e a transfusão do sangue ao passo que, para SPIEZIA, esta é lícita, não a extração e o transplante de órgãos.

Operação realizada no Líbano, ao que noticiavam os jornais do dia 23-05-1972, poderá contribuir para modificar muitos conceitos. $\mathrm{O}$ cirurgião Kamal Hanache, pela primeira vez, no mundo, teria enxertado testículos retirados de um feto de sete meses, natimorto, num paciente de 26 anos. 0 receptor havia nascido sem o órgão, hipótese rara, e sofria de alergia aos hormônios masculinos. Caso venha a procriar, o filho terá as características genéticas do doador.

A matéria volta a ter grande atualidade com o aperfeiçoamento da técnica do transplante de ovários.

No X Congresso Brasileiro de Ginecologia e Obstetrícia, iniciado em Curitiba em data de 26-10-1972 ARTUR CAMPOS DA PAZ encareceu representar esse transplante área controvertida, pelas suas implicações psicológicas (a mulher receptora não adquire, a rigor, a condição de mãe) e médico-legais.

Manifestou-se contrário a semelhante transplante, considerando "muito melhor a adoção de uma criança", informando que, até aquela ocasião, somente alguns poucos profissionais já haviam realizado a operação.

Até princípios de agosto de 1974 GUENTER WILLITAL, da Clínica da Universidade de Erlangen, Alemanha, depois de 
ter-se preparado longamento executando operações em animais, realizou cerca de dez transplantes, com êxito, de tecidos cerebrais de bebês mortos para salvar a vida de recém-nascidos com malformações musculares.

Os tecidos utilizados, as meninges que envolvem o cérebro, não apresentaram sintomas de rejeição, sendo absorvidos e transformados em outro no prazo de três meses.

Informou que o emprego de tecidos das meninges não é novo: a novidade consiste na sua utilização em recém-nascidos com defeitos congênitos, que de outra maneira estariam fadados à morte, em pouco tempo.

A doutrina considerou, a princípio, proibido e inválido o consentimento à retirada e ao transplante da própria córnea ocular e de um rim em favor de outra pessoa, porque dessa retirada decorre um enfraquecimento permanente do órgão da vista, além do perigo da perda completa da função visual, ao contrário do que acontece com a transfusão do sangue, por não ocorrer diminuição permanente da integridade física.

Mas Paulo José da Costa JR., O Transplante do Coração Face ao Direito Brasileiro, in Justitia, V. 60, p. 109, invocando o caso de transplante de rim, ocorrido na Itália, no qual o médico respondeu a processo-crime pela morte do doador e do paciente, sendo afinal absolvido pelo reconhecimento da excludente do estado de necessidade, informa que as dúvidas foram dissipadas com a Lei peninsular n. ${ }^{\circ} 158$, de 26-07-1967, que autoriza a disposição do rim em estado de necessidade a título gratuito, entre pessoas vivas, desde que pais, filhos ou irmãos do paciente, maiores de idade, manifestem seu consentimento indicadas as demais exigências.

Esse mesmo autor informa que, dos 1200 transplantes até então realizados em todo o mundo, nenhum doador havia morrido, por ter permanecido com um único rim, enquanto que, dos pacientes, apenas por mais alguns anos havia sido possível prorrogar a vida.

No Brasil, dos 394 transplantes renais, entre estranhos, a sobrevida mais longa foi de dois anos. Dos 36 transplantes feitos em gêmeos univitelinos, 27 tiveram êxito, com sobrevida máxima de sete anos. Dos 111 transplantes entre irmãos, houve 61 sobrevidas, das quais a mais longa de seis anos. E dos 189 transplantes entre parentes consangüíneos, 94 sobreviveram, no máximo, por três anos. 
Mais precário ainda o êxito do transplante de corações, só o progresso da ciência justificando, a continuação das pesquisas.

A preocupação volta-se para a criação de um coração artificial, que, prevê-se, uma vez levada a efeito, levantará graves questões de natureza moral, legal e social.

Um estudo do Instituto Nacional de Enfermidades Cardíacas e Pulmonares dos Estados Unidos da América do Norte divulgou, no ano de 1973, um comunicado elaborado por um grupo de dez médicos, advogados, sociólogos, moralistas e políticos, encarecendo que, vendido a um custo de aproximadamente 25 mil dólares, só seria acessível aos ricos, caso não fosse concedida uma ajuda econômica aos dele necessitados.

Dada a insuficiência de corações artificiais de início suficientes, à dificuldade da seleção dos beneficiados, que deverá obedecer critérios médicos rigorosos, outra será acrescida: a da determinação da morte de pessoas dotadas de coração artificial, que irá fazer o sangue circular depois da morte de outros órgãos.

Qual a conclusão a ser retirada, em linhas gerais?

Predomina o consenso no princípio, expresso pelo referido CARAVELli, de que uma orientação deve resultar de um dispositivo legal explícito: para os bens não declarados inalienáveis, a inalienabilidade só pode ocorrer "quando do fato resulte uma violação do interesse público ou mesmo de um direito privado alheio, como, por exemplo ocorreria na autolesão do segurado, objetivando obter o prêmio, na mutilação voluntária de quem está sujeito a obrigações militares e casos semelhantes."

Conclui que unicamente nestes casos pode-se falar de ilícita violação da integridade física. Entende que a hipótese considerada, por não perturbar qualquer direito alheio, permanece dentro da esfera das relações individuais. Não se podendo sequer dizer que ofenda os sentimentos sociais, deve necessariamente enquadrar-se na atividade lícita, da mesma forma que o boxe e tantos outros esportes, dos quais muitas vezes decorrem piores conseqüências. Cita, a propósito, vários acórdãos.

\section{Direito ao Cadáver.}

A maioria das legislações consagra a proteção aos mortos, tendo em conta - frisa MOACYR DE Oliveira, Do Estado de 
Necessidade (O Exemplo dos Andes), in Rev. dos Tribunais, v. 450,1973 , ps. $474-481$ — valores éticos-sociais a serem resguardados.

Realça o sentimento de piedade: o respeito aos mortos transcende um misto de religiosidade e superstição. Mais rigorosas sanções o cercavam em tempos de fanatismo, misticismo e fetichismo, relacionados com idéias animistas.

"Poderosas virtudes, qualidades mágicas e hipnóticas acreditava-se emanarem das partes do cadáver, criando-se seitas de adoradores de restos humanos, aproveitáveis para as artes da "bruxaria" e para fins medicinais. Gordura de defuntos era vendida em farmácias, a princípio oficialmente, por ser subproduto dos criminosos executados em público. Depois que cessaram as execuções, violavam-se as sepulturas, para aquisição do "medicamento".

Pela pouca incidência dos crimes de profanação do morto, as penas vêm-se abrandando e se tornam letra morta nos Códigos. Pertencem ao reino das lendas o vampirismo, a anecrofagia, a nigromancia, e rara é nos anais forenses a aberração sexual conhecida por necrofilia. Dissipa-se aos poucos o halo sobrenatural da morte, sem perda do dever sagrado do culto à memória dos antepassados. Acima do interesse religioso ou supersticíoso, paira o interesse científico, intervindo, pelo progresso da técnica dos transplantes, para que a lei possibilite o maior aproveitamento cirúrgico dos despojos humanos."

O cadáver interessa ao nosso estudo sob três aspectos fundamentais.

Sob o ponto de vista do Código Penal, é objeto de quatro dispositivos, dos arts. 209-212, subordinados à epígrafe Dos Crimes cortra o Respeito aos Mortos, considerando, sucessivamente: impedimento ou perturbação de cerimônia funerária; violação de sepultura; destruição, subtração ou ocultação de cadáver e vilipêndio a cadáver.

Sob o ponto de vista administrativo, o interesse fundamental diz respeito à organização dos cemitérios. 
A Constituição Imperial de 25-03-1824, nada consignando, deixava ampla liberdade tanto à iniciativa das irmandades religiosas, como de qualquer pessoa física ou jurídica.

Projeto de lei apresentado por Saldanha Marinho, depois de célebre discussão, foi convertido em 27-09-1890, no Decreto n. ${ }^{\circ} 789$, outorgando "às municipalidades a polícia, direção e administração dos cemitérios, sem a intervenção, ou dependência de qualquer autoridade religiosa."

A Constituição de 24-02-1891 determinou, art. 72, § 5. , fossem eles administrados pela autoridade municipal, ficando livre a todos os cultos religiosos a prática dos respectivos ritos em relação aos seus crentes, desde que não ofendessem a moral pública e as leis.

A de 16-07-1934 manteve a primeira parte, mas concedeu uma maior abertura, admitindo, na segunda parte, a manutenção de cemitérios particulares por parte das associações religiosas, "sujeitos, porém, à fiscalização das autoridades competentes", ficando-lhes proibida a recusa de sepultura onde não houver cemitério particular.

A de 10-11-1937, n. ${ }^{\circ}$ 5, procurou restabelecer a impossível secularidade exclusiva dos cemitérios, determinando fossem administrados pela autoridade municipal.

A de 18-09-1946 voltou a considerar a matéria com maior largueza, embora mantendo a secularidade e a administração municipal, admitindo também a manutenção de particulares (art. 141, § 10).

A Constituição de 24-01-1967 e a Emenda n. ${ }^{\circ} 1$ de 17-10-1969 riscaram completamente o dispositivo.

Não se podendo cogitar de esquecimento de matéria tão importante, a conclusão é que a omissão foi proposital, implicando na revogação tácita do dispositivo anterior, com ressalva dos direitos já adquiridos.

Nos termos do Decreto-lei complementar n. ${ }^{\circ}$ 9, de 31-12-1969, do Estado de S. Paulo, que "dispõe sobre a organização dos Municípios", compete ao Município - art. 2. n. ${ }^{\circ} \mathrm{XVI}$ - dispor sobre o serviço funerário e cemitérios, encarregando-se da administração daqueles que forem públicos e fiscalizando os pertencentes a entidades privadas.

A lei municipal paulista n. ${ }^{\circ} 4100$, de 06-09-1951, por sua vez, que dispõe sobre cemitérios particulares reserva à Prefeitura Municipal competência para autorizar a utilização de 
terrenos para a ereção de cemitérios particulares, que permanecerão sob sua fiscalização.

Mas é sob o terceiro aspecto, o do direito privado, que a matéria interessa de modo particular.

W. G., Derecho al cadáver, in Diccionario de Derecho Privado, Barcelona, Labor, 1961, t. I, p. 1451, enumera as teorias mais divulgadas a respeito da natureza jurídica do cadáver, que agrupa conforme consideram-no como coisa, aos efeitos jurídicos, e as que lhe negam essa qualidade.

Da mesma forma que o direito sobre as partes separadas do corpo humano observa ADRIANo DE CUPIS, não se incluiu na categoria dos direitos da personalidade, mas tradicionalmente seu estudo está relacionado com a mesma.

"As partes desunidas do corpo humano são partes, porções do corpo humano, que, por efeito da separação, não são mais, propriamente, tais, isto é partes do mesmo corpo humano. O cadáver, ao invés, é o inteiro corpo humano, que, por efeito da morte, não é mais, propriamente, corpo humano, mas, justamente, cadáver. São coisas (res), como se viu, as partes separadas; e é coisa, igualmente, o cadáver. Mas enquanto para as primeiras é a separação que faz com que assumam a qualificação real, para o cadáver, que é tal em virtude da morte, é a própria morte que assinala o início e determina o surgimento da qualificação real".

Acentua que o respeito coletivo pelo cadáver corresponde ao traço de humanidade que nele persiste, e exige seja conservada a sua dignidade, o que impede qualquer forma de utilização econômica, e separa, analisando minuciosamente, as duas diferentes figuras que ele pode assumir: direito sobre o próprio cadáver e direito sobre o cadáver alheio.

O cadáver é coisa extra commercium, não suscetível de direitos privados patrimoniais, mas, por outro lado, é objeto de um direito privado não patrimonial, de origem consuetudinária, e que tem por conteúdo a faculdade de determinar o modo e a forma de seu destino normal. Trata-se de um direito familiar, que corresponde aos parentes do defunto em razão do sentimento de piedade que os liga à pessoa falecida, e, conseqüentemente, de um direito-dever, que tem como pressuposto negativo que o defunto não tenha manifestado sua 
vontade a respeito. Ela pode desenvolver-se com maior amplitude, inclusive destinando seu cadáver a um instituto científico ou à mesa anatômica.

Entre nós, em lúcido comentário a um acórdão do Tribunal de Justiça do Rio Grande do Sul, Rev. de Crítica Judiciária, v. 31, p. 135 e seguintes, ARNOLdo MEDEIROS DA FonseCA reconhece, com FERRARA, a natureza familiar do direito sobre o cadáver, que não passa de um direito-dever, concedido, não para a utilidade de seu titular, mas, para permitir aos membros da família o desempenho do dever de tributarem as últimas homenagens ao finado, proverem sobre o seu sepultamento e cerimônias fúnebres, se ele próprio não houver disposto a respeito, devendo-se assim atender aos liames de sangue e de matrimônio para fixar quem o pode exercer, sem que, entretanto, com isso, deixe o cadáver de ser res extra commercium, só objeto de outros direitos privados excepcionalmente, quando a lei ou vontade do defunto hajam permitido um uso lícito, como os estudos anatômicos. Acrescenta.

"Mas isso nada tem que ver com o direito sobre a sepultura, que é coisa muito diversa.

Se a mãe do Autor não era casada validamente com o Réu, podia aquele impedir o seu sepultamento no túmulo adquirido por este. Não o fez, porém, consentindo, na sua inumação em tal local. O seu possível direito a prover sobre o destino do cadáver cessou, portanto, ou melhor, exerceu-se desse modo".

José CASTAN ToBenas, que faz um balanço das opiniões a respeito, chega à conclusão, perfeitamente adaptável ao nosso regime, de que seu direito, como a generalidade dos demais, não registra preceitos legislativos exclusivamente com o problema jurídico-civil do cadáver. Existem somente disposições administrativas que limitam a liberdade de enterro, por razões. de segurança, salubridade e moralidade pública, estabelecendo as condições para a inumação, autópsia, translação de restos, etc.

"Mas, substancialmente, cabe aceitar, com relação ao aludido problema, soluções concordantes com as da doutrina estrangeira. O cadáver não é coisa suscetível de apropriação e comércio, mas res extra commercium, sujeita a normas de interesse público e social. Protege-se-o impondo penas aos 
que contrariarem as leis ou regulamentos sobre inumações e aos que faltando ao respeito devido à memória dos mortos, violarem os sepulcros ou sepulturas ou praticarem quaisquer atos de profanação de cadáveres".

O projeto ORLANDo Gomes previa: Art. 30. "Disposição do Cadáver. É válida a disposição gratuita do próprio corpo, no todo ou em parte, para depois de sua morte, para fins científicos.

Parágrafo único. $\mathrm{O}$ ato de disposição pode ser revogado a todo tempo."

A proposição foi acolhida pelo Projeto de Código Civil de 1975 :

"Art. 14. É válida, com objetivo científico, ou altruístico, a disposição gratuita do próprio corpo, no todo ou em parte, para depois da morte.

Parágrafo único. Admitir-se-ão, porém, tais atos para fins de transplante, na forma estabelecida em lei especial."

\section{Retirada de órgãos ou de Partes de Cadáver.}

Já examinamos a Lei n. ${ }^{0} 5479$, de 10-08-1968, no único artigo, o 10, que admite a retirada de órgãos e partes de pessoa viva, maior e capaz.

Os demais dispositivos, todos relativos à disposição gratuita de uma ou de várias partes do corpo, post mortem, para fins terapêuticos (art. $1 .^{\circ}$ ), cuidam das seguintes matérias principais :

1. Prévia prova incontestável $d a$ morte para a disposição referida (art. $2 .^{\circ}$ ).

É sem dúvida essa a exigência fundamental, sob pena de se admitir a possibilidade de verdadeiros crimes, dando sempre margem, por maiores que sejam as cautelas, a surpresas.

Como a proporcionada pelo garoto Jason Arthur Rae, dado como morto ao sofrer no dia 14-07-1973, uma grave lesão cerebral, numa piscina, na Califórnia, tendo sua mãe autorizado o transplante de seus rins e figado.

Quando os cirurgiões de um hospital de Denver se preparavam para a operação, perceberam que o suposto cadáver 
respondia aos estímulos da dor, tendo sua respiração sido restabelecida 45 minutos depois.

A imprensa lembrou, na ocasião, as experiências do cientista russo VICTOR BuKov, que conseguiu fazer um cão voltar à vida depois de três dias de seu coração ter parado de bater, tendo submetido seu cérebro a um processo de resfriamento.

Até então acreditavam todos que a morte se dá quando o coração pára e a respiração se interrompe. A descoberta de que não é o coração que marca o fim da vida, mas o cérebro, abriu novas perspectivas para os cientistas.

Até realizar a sua primeira experiência, o professor Bukov unia mentalmente dois fenômenos aparentemente desvinculados: o resfriamento do cérebro e a anoxia das células cerebrais (falta de oxigenio).

Como quanto mais desce a temperatura no cérebro, mais diminui a quota de oxigenio de que necessitam as células, queria saber se não seria possível o frio prolongar o limite de destruição das células da cortex cerebral.

Submeteu o paciente ao esfriamento do cérebro, que é aplicado no intervalo entre a morte clínica (primeira morte, quando o coração pára e a respiração se interrompe) e a morte biológica (quando a camada superfícial do cérebro, a cortex, é atingida).

Não havia ainda pensado em passar da experimentação em laboratório para a aplicação clínica, quando foi forçado a fazê-lo, tendo sido convocado a reanimar o primeiro ser humano pelo frio: uma menina, Marina, que chegou a Moscou, de muito longe, e foi internada no Instituto de Investigações de Obstetrícia e Ginecologia.

$\mathrm{Na}$ sala de operações, uma equipe de médicos cercou a paciente, que já tinha sofrido duas paradas cardíacas. Depois de terem feito inutilmente todas as tentativas para reanimá-la, lembraram de Bukov, que, picando gelo para encher um capacete, pois não podia transportar a sua pesada instalação frigorífica para o hospital, conseguiu fazê-la voltar a si e, dois dias depois, extraía raízes quadradas de memória, para provar sua normalidade.

2. Satisfação de uma das seguintes condições jurídicas para que seja reconhecida validade à permissão para o aproveitamento (art. $3 .^{\circ}$ ) : 
I - manifestação expressa da vontade do disponente;

II - manifestação da vontade através de instrumento público, quando se tratar de disponentes relativamente incapazes e de analfabetos;

III - autorização escrita do cônjuge, não separado, e sucessivamente, de descendentes e colaterais, ou das corporações religiosas ou civis responsáveis pelo destino dos despojos;

IV - na falta de responsáveis pelo cadáver, a retirada somente poderá ser feita com a autorização do Diretor da Instituição onde ocorrer o óbito, sendo ainda necessária esta autorização nas condições dos itens anteriores.

O Instituto dos Advogados de S. Paulo promoveu, em 1968, um concurso de teses sobre o tema O Transplante de órgãos Humanos à Luz do Direito, resultando classificados três vencedores: Jost́ FrEITAS NobRE, JoÃo GUALBERTo DE OLIVEIRA e MoACir DE Oliveira, tendo a primeira e a segunda sido publicadas respectivamente por Coordenada, de Brasília, e Bentivegna, de S. Paulo.

A orientação mais plausível é a inversa : em vez de admitir a utilização de partes do cadáver como exceção, mediante autorização, presumir a aquiescência, salvo manifestação contrária.

É nesse sentido - lembra FrEITAS Nobre - a legislação da Tchecoeslováquia, dispondo o Decreto n. ${ }^{\circ} 47$, de 1966, art. 8 , alínea 3, que todo o cidadão tem o direito de receber todos os cuidados médicos de que necessite, inclusive os transplantes, com a utilização de órgãos do morto, salvo a hipótese em que este, em vida, tenha expressamente proibido essa mutilação.

Não havendo compatibilidade, admite o art. $7 .^{\circ}$ que a destinação a determinada pessoa seja, a critério do médico chefe da instituição, a mediante prévia disposição ou autorização de quem de direito, transferida para outro receptor, em que se verifique aquela condição.

3. Autorização prévia pelo médico-legista da retirada de partes do cadáver, sujeito por força de lei à necrópsia ou à verificação diagnóstica causa mortis, citada no relatório da necrópsia ou da verificação diagnóstica (art. $8 .^{\circ}$ ) ficando ainda expressamente proibidas as intervenções de que cogita essa lei se houver suspeita de ser o disponente vítima de crime (art. 12).

Faz ver Freitas Nobre que, alheios ao exame jurídico do problema, os cirurgiões se preocupam enormemente com $o$ 
dispositivo, considerando todos os fornecedores vítimas de crime impedidos de fornecer órgãos para o transplante. De toda evidência que o dispositivo se refere a crimes dolosos contra a vida, os quais exigem para a apuração delituosa correspondente o exame médico-legal circunstanciado capaz de esclarecer a responsabilidade pela autoria, a gravidade das lesões, etc.

"Nada impede, porém," - acrescenta, que os cirurgiões da equipe do transplante façam o exame médico-legal e apresentem o laudo respectivo.

Mas, se fôssemos corrigir a redação do art. 12, teria sido preciso, também, substituir aquele disponente, que já não dispõe, que já não doa, por termo mais ajustado juridicamente ao texto legal."

Everardo DA Cunha Luna, Disciplina Jurídica do Transplante, in Justitia, v. 64, 1969, sustenta que a proibição legal atinge o caso em que o disponente for vítima de suicídio. Embora a lei não o considere crime, por motivo de política criminal, não resta dúvida que se trata de um ato ilícito, e a compreensão dessa palavra, contida no referido art. 12, não se destinando a fins penais, independe de interpretação estrita: crime, no caso, seria "o ato ilícito ofensivo da vida ou da integridade corporal do disponente".

4. Requisitos técnicos para a retirada e o transplante: o art. $4 .^{\circ}$ somente admite sejam realizados por médicos de capacidade comprovada, em instituições públicas ou particulares reconhecidas idôneas e autorizadas pelos órgãos públicos competentes, somente podendo ser realizado o transplante se o paciente não tiver possibilidade alguma de melhorar através de tratamento médico ou outra ação cirúrgica.

Distingue FrEITAS NOBRE entre doador e fornecedor: embora todo doador seja um fornecedor, nem todo fornecedor é um doador.

Opõe restrições à exigência de que as instituições públicas ou particulares devam ser autorizadas pelos referidos órgãos: desde que devidamente treinado, o médico está capacitado, sem necessitar de autorização extra.

Realça o absurdo de se estabelecerem duas categorias de médicos, os autorizados e os não autorizados, pois não estão ęleș realizandọ atos profisșionais alheios à sua competência. 
5. Obrigatoriedade dos Diretores das instituições hospitalares ou institutos universitários de comunicar ao Diretor da Saúde Pública quais as pessoas que fizeram disposições para "post mortem" de seus tecidos ou órgãos, com destino a transplante e o nome das instituições ou pessoas contempladas (art. $5 .^{\circ}$ ), bem como de remeterem ao fim de cada ano, ao Departamento Nacional de Saúde Pública, os relatórios dos atos cirúrgicos relativos a essas retiradas, bem como os resultados dessas operações (art. $8^{\circ}$ ).

6. Feita a retirada, impõe o art. $6 .^{\circ}$ e seu parágrafo seja - cadáver condignamente recomposto e entregue aos responsáveis para o sepultamento, sob a pena prevista no art. 211 do Código Penal.

Critica FReitas NobRe o texto por não precisar de quem essa responsabilidade, entendendendo que, no caso de recusa do hospital em recompor o cadáver, deve ela ser transferida à equipe que realizou a intervenção, aproveitando a peça orgânica.

"É evidente que em casos como o da extração de olhos, estes podem ser substituidos com outros artificiais, porém no caso de órgãos ou outras peças internas será suficiente que a apresentação exterior do cadáver não indique a mutilação executada."

7. A lei exige a gratuidade da peça extraída, mas prevê, art. 13 despesas com as retiradas e transplantes, cuja disciplina remete à regulamentação da lei.

Os gastos - observa o operoso parlamentar - além de serem sensíveis em operações dessa natureza, decorrem também de uma diminuição do atendimento de numerosos pacientes, face às medidas preventivas e posteriores de reabilitação, que não se sabe como serão computadas.

0 inconveniente maior é que a Lei $n .^{\circ} 5479$, para sua execução, depende de regulamentação, prevista para 60 dias após a sua publicação (art. 15), mas até agora não efetivada.

Conclui, por isso, deverá esta ser feita dentro do quadro do progresso da imunopatologia, "a fim de que somente se efetue o transplanta quando a adaptação hemodiânica do coração a enxertar-se no donatário seja possível e quando essa adaptação também corresponda a do corpo receptor beneficiário do órgão enxertado". 
8. A lei comina, para a infração ao disposto nos arts. $2 .^{\circ}$ (prova prévia da morte), $3 .^{\circ}$ (autorização para o aproveitamento) $4 .^{\circ}$ (retirada e transplante realizados por médico de capacidade técnica comprovada) $5 .^{\circ}$ (comunicação dos Diretores), pena de detenção de um a três anos, sem prejuízo de outras sanções que no caso couberem.

9. O art. 14 indica o Departamento Nacional de Saúde Pública como órgão fiscalizador da execução da Lei.

\section{A Antropofagia Necessária.}

Insere-se, no estudo do respeito ao cadáver, o problema da antropologia famélica.

A história registra numerosos casos de indivíduos que, vítimas de circunstâncias inesperadas, tiveram que alimentar-se de companheiros mortos, quando não matar um deles por uma questão de mera sobrevivência.

Limitando-nos ao registro dos casos mais conhecidos entre pessoas civilizadas, H. Donnedieu DE VABRes, A Justiça Penal de Hoje, Coimbra, Amado, trad. 1962, p. 39, invoca o caso dos náufragos do "Mignonette", que, isolados numa jangada, mataram um moço de bordo para lhe comer a carne e beber o sangue.

MANZINI, em seu Trattato, lembra o caso de três homens que, em 1927, surpreendidos na metade do caminho de San Juan, na Argentina, para o Chile, em plenos Andes, pela falta de alimentos, assassinaram um quarto companheiro, para servir de repasto, respondendo a processo que afinal foi arquivado, no foro argentino.

Em janeiro de 1973 outro caso ocorreu na mesma cordilheira: sobreviventes de um desastre aéreo confessaram ter comido carne humana para não morrerem.

MoACYR DE Oliveira, em seu artigo já citado, procede a um minucioso estudo desses casos, lembrado que J. MAXWELL, doutor em Medicina e procurador de um dos tribunais de Paris, em $O$ Crime e a Sociedade, estabeleceu a separação entre a criminalidade e a moralidade, destacando-lhes os domínios: "Atos morais existem que são punidos; outros, imorais, não o são".

$\mathrm{Na}$ pesquisa das leis, surpreende-se com as disposições do Código de Manu (Lei n. ${ }^{\circ} 105$, livro X), que fazia impunes 
atos de antropofagia quando significavam remédio contra a fome.

A Lei das Sete Partidas (n. ${ }^{\circ}$ IV, tít. XVII, Lei n. ${ }^{\circ} 8$ ), determinava ao pai acossado pela fome, em castelo sitiado, que antes se alimentasse do filho, do que entregar o castelo sem mandato de seu senhor.

Transcreve passagem do citado DoNNEDIEU DE VABRES :

"A moral não justifica, nem desculpa os atos desses infelizes que, (nos incêndios do "Bazar da Caridade", em Paris, e do "Teatro de las Novelladas", de Madrid) sob a ameaça iminente de uma morte horrorosa, abrem caminho através da multidão, à navalhada ou à cacetada. Mas a lei penal não manda que se seja herói. Entre duas vidas humanas, uma das quais, ainda que numa manifestação de feroz egoísmo, foi imolada à outra, ela não tem o direito de escolher. $\mathrm{E}$ não castiga, porque o interesse social não está em jogo."

Chega o Professor de Direito Civil da Faculdade de Direito da Universidade Federal de Santa Catarina, por entre eruditas considerações, à conclusão de que os responsáveis por atos de antropofagia, em condições de necessidade que possam ser provadas em juízo, não incidem em crime.

Evitam um mal em toda sua cruel realidade: o perigo iminente, atual, grave, fatal de inanição e morte.

Faz ver, com ENNECERUS-KIPP-WOLFF e THUR, subentender-se sempre o mal evitado bem maior que o sacrificado, a vida de uma pessoa humana, caso em que todos os demais bens são de valor inferior.

Entre a pessoa viva e a pessoa morta a desproporção é enorme: a impunidade vem da ação da força irresistível (o instinto de conservação do homem), do medo insuperável (a morte iminente inevitável).

"Aos que tiveram o infortúnio de se alimentar de carne humana" - concluiu - "não só o Direito, a Justiça os ampara, compreendendo que não representam perigo para a sociedade, nas circunstâncias em que agiram. A Religião perdoa-os, sabido que o Homem embora inclinado para Deus sente nos ombros a lei oposta à do espírito e que o 
faz escravo da lei do pecado (Epístola aos Romanos, 7, 22-3). A Filosofia consola-os, falando na luta interior do Homem entre a Razão e as Paixões, que o traz sempre dividido como seu próprio adversário, no antagonismo da natureza humana. "A grandeza do Homem é grande, porque o Homem sabe que é miserável. Só se pode ser miserável, compreendendo que o é. O Homem é o único ser miserável que existe" (Pascal)."

\section{Bibliografia.}

Brasiello, Teucro, Persona Propria. Diritti sulla) in Dizionario Pratico del Diritto Privato, Milão, Vallardi, v. V, parte I, 1939, p. 527-532.

Cunha Gonçalves, Luiz da, Tratado de Direito Civil, S. Paulo, Limonad, $2 .^{a}$ edição, v. I, t. I, 1955, p. 188-197.

De Cupis, Adriano, I Diritti della Personalitá, Milão, Giuffrè, 1959, dois tomos, 371, 271 páginas.

Perlingieri, Pietro, La personalità umana nell'ordinamento giuridico, Camerino, Jovene, 1972, 551 páginas.

Santamaria, Mässimo Ferrara, Persona (Diritti della) in Nuovo Digesto Italiano; Turim, Utẹt, v. IX, 1939, p. 912-928.

Todolı, José, Ética dos Transplantes, S. Paulo, Herder, tradução, 86 páginas.

Vassali, Giuliano, A Proteção na Esfera da Personalidade na Era da Técnica, tradução, in Justitia, S. Paulo, v. 56 1967, p. 39-76. 